Portland State University

PDXScholar

$5-11-1990$

\title{
Burns'eko etxekoandreak. Basque Women Boarding House Keepers of Burns, Oregon
}

Paquita Lucia Garatea
Portland State University

Follow this and additional works at: https://pdxscholar.library.pdx.edu/open_access_etds

Part of the Women's History Commons

Let us know how access to this document benefits you.

\section{Recommended Citation}

Garatea, Paquita Lucia, "Burns'eko etxekoandreak: Basque Women Boarding House Keepers of Burns, Oregon" (1990). Dissertations and Theses. Paper 3975.

https://doi.org/10.15760/etd.5856

This Thesis is brought to you for free and open access. It has been accepted for inclusion in Dissertations and Theses by an authorized administrator of PDXScholar. Please contact us if we can make this document more accessible: pdxscholar@pdx.edu. 


\section{AN ABSTRACT OF THE THESIS OF Paquita Lucia Garatea for the}

Master of Arts in History presented May 11, 1990.

Title: Burns'eko Etxekoandreak: Basque Women Boarding House Keepers of Burns, Oregon.

\section{APPROVED BY THE MEMBERS OF THE THESIS COMMITTEE:}

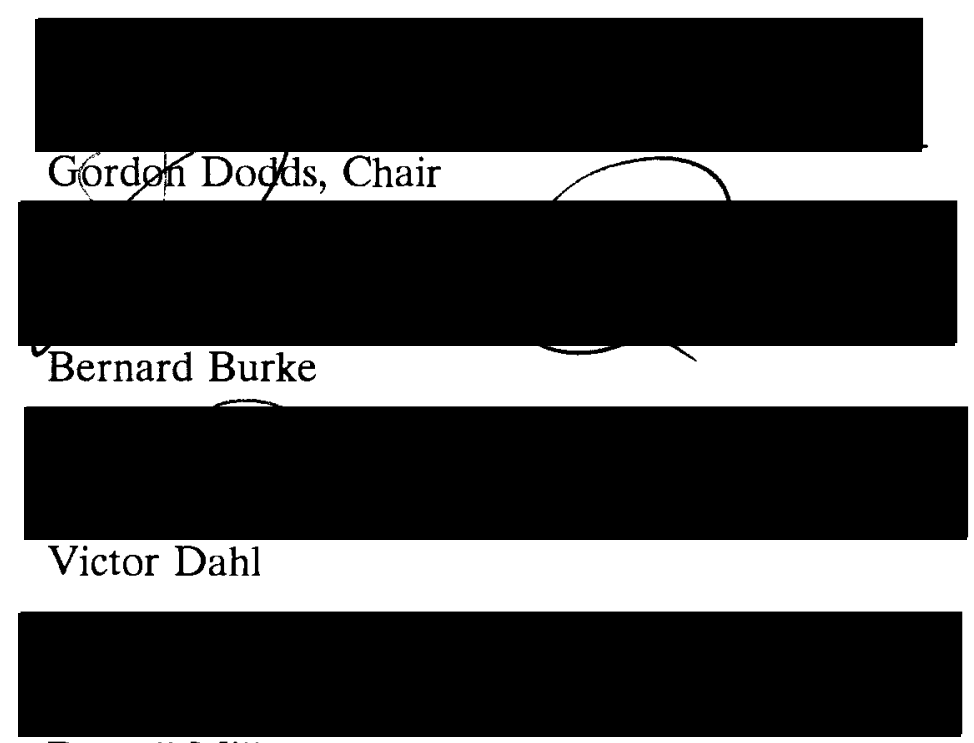

Darrell Millner

The migration of the Basques to the Pacific Northwest at the turn of the century was due to a number of factors including economic, cultural and political. The Basques constitute a distinct ethnic group from northern Spain and southern France, whose origins have not yet been determined by historical, linguistic, or archaeological studies. From ancient times, the Basques have fought to maintain their cultural identity and political freedom against invaders, developing in this struggle a strong sense of racial group solidarity. The lack of opportunity for 
advancement and the obligation to serve in the military were added reasons for the journey to America, as an alternative to political and cultural oppression.

The Basque migration to the Northwest was, in addition, an extension of the Latin American sheep industry which had been contracting Basques as immigrant herders. Many of the Basques who migrated to Oregon had never tended a herd of sheep in their lives but the most accessible opportunities for economic advancement were within the confines of this particular industry. By the 1920 s the Northwest sheep industry was dominated by the Basque immigrants. To accommodate and serve this growing population, Basque boarding houses began to appear and were instrumental in the growth of towns in eastern Oregon, such as Burns. The establishments were managed and maintained primarily by immigrant Basque women who were responsible or the marketing, cooking, cleaning and the extensive bookkeeping involved. The boarding houses became the means for the maintenance of Basque cultural identity, providing a locus for the practice of traditional Basque customs and language.

The focus of this study is on the women who managed these establishments and who, until now, have been left out of the historical record. Interviews with these women, their families and associates created a large body of primary historical evidence that clearly shows the importance and contribution of Basque women to the growth of towns in eastern Oregon and to the maintenance of the ancient Basque culture. 
BURNS'EKO ETXEKOANDREAK:

BASQUE WOMEN BOARDING HOUSE KEEPERS OF BURNS, OREGON

by

PAQUITA LUCIA GARATEA

A thesis submitted in partial fulfillment of the

requirements for the degree of

MASTER OF ARTS

in

HISTORY

Portland State University

1990 


\section{TO THE OFFICE OF GRADUATE STUDIES:}

The members of the Committee approve the thesis of

Paquita Lucia Garatea presented May 11, 1990.

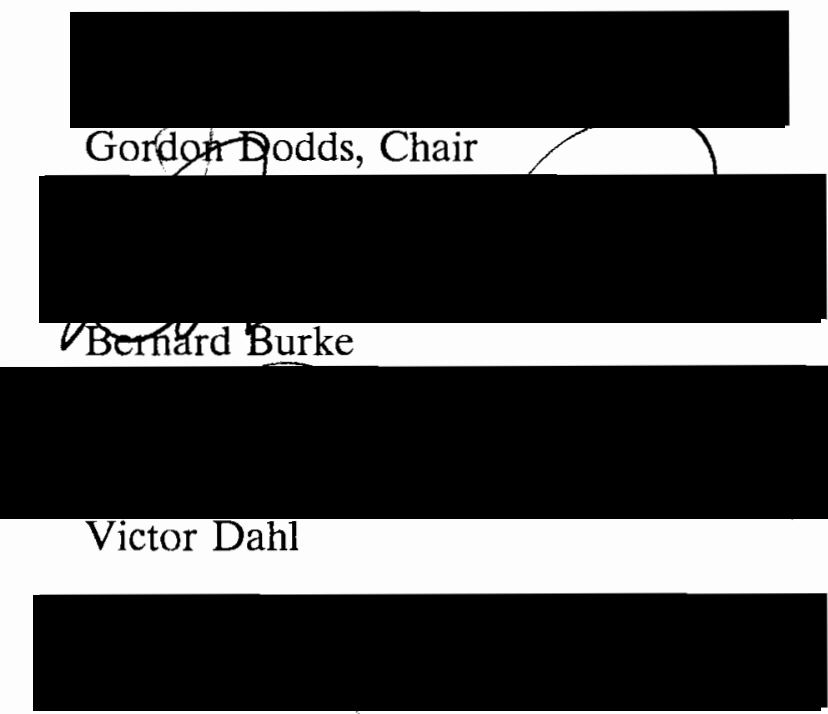

Darrell Millner

APPROVED:

Bernar\&V. Burke, Chair, Department of History

C. William Savery, Interim Vice Proyøst for Graduate Studies and Research 
THIS STUDY IS DEDICATED

TO

THE LOVING MEMORY

OF

MARGARITA ARAMAIO OSA

1897-1989 


\section{ACKNOWLEDGEMENTS}

When first beginning the research for this study, I would return home from libraries frustrated and disappointed that there were so few references about Basque women. It seemed as if the historical existence of Basque women had either been entirely ignored or forgotten. Since these same women had played such an important role in my life, I decided to write about them and their experiences. Through interviews with Basque women, both in the Basque Country (Euzkadi) and in the Pacific Northwest, and with their children and acquaintances, this study began to take on a second topical focus, the Basque boarding houses (Ostatuak). Using this New World institution as a backdrop, I have attempted to capture the important role of the Basque female head-of-household (etxekoandrea) who has too often been left out of the historical record.

There are numerous people who have helped me through this process, especially my mother, Margarita Osa Garatea, whose love, inspiration and reassurance never falters. To my son, Jonas Marcel, who has spent many hours patiently waiting for his busy mother to complete this project, I am so grateful. My father, Henry Garatea who passed away in 1988, was always willing to lend a helping hand and was mainly responsible for my opportunity to live and conduct research in the Basque Country. The generosity and kindness of my cousins in Euzkadi allowed 
my son and I to live very comfortably during our stay and they will never be forgotten.

To all of the Basque women who so graciously let me record their crucial life histories, I am forever thankful. Mrs. Peggy Sitz, the Harney County Librarian and also my godmother, provided numerous leads and assistance for this study and she is very appreciated. My cousin, Mrs. Elvira Zabala, not only allowed me to tape her life history but she also lent her personal photographs for this study, as did Mrs. Maria Lete. Elvira's daughter, Gloria Zabala, consistently helped with her expertise in the translation of interviews and text, both in the Basque and Spanish languages. Jerry Bridges also contributed substantially by creating the negatives and copies of the photos exhibited. Karen Jacobson-Zabala, of the Harney County Assessor's office, provided the structural information and copies of the deeds for both the Plaza and Star Boarding Houses. After my grandmother (Amuma) Margarita Osa's death in 1989, I relied on my aunt, Connie Osa Corbet, and her husband Dick, and my uncle, Joe Garatea, for their hospitality and willingness to provide room for their niece while staying in Burns.

The Department of History at Portland State University, with its kind and helpful secretaries, Lee Ellington and Diane Gould, and its distinguished Chair, Dr. Bernard Burke, helped in many ways too numerous to mention. Professor Gordon Dodds, a noted Oregon historian, played a key role in advising and patiently editing my work, always with enthusiasm and much encouragement. Included in my acknowledgements are two professors from the Department of Black Studies at 
Portland State University, Dr. Candice Goucher, for her exceptional teaching skills and the encouragement to pursue the idea of this thesis and also Dr. Darrell Millner for his continuous support and help. Lastly, I would like to mention a dear friend and collegue, Richard Dellenback, for his creative ideas and for his gracious help with the editing and proofreading of the text. To all of those I have mentioned and to those I have unknowingly neglected, eskerrik asko (many thanks). 
TABLE OF CONTENTS

PAGE

ACKNOWLEDGEMENTS $\ldots \ldots \ldots \ldots \ldots \ldots \ldots \ldots \ldots \ldots \ldots \ldots \ldots \ldots$ iii

LIST OF FIGURES $\ldots \ldots \ldots \ldots \ldots \ldots \ldots \ldots \ldots \ldots \ldots \ldots \ldots \ldots \ldots \ldots$

\section{CHAPTER}

I HISTORICAL OVERVIEW OF EUZKADI (BASQUE COUNTRY): SCHOLARSHIP AND DEBATE $\ldots \ldots \ldots \ldots 1$

II THE SHEEP INDUSTRY AND BASQUE IMMIGRATION TO HARNEY COUNTY, OREGON $\ldots \ldots \ldots \ldots \ldots 15$

III THE BASQUE BOARDING HOUSES (OSTATUAK): AN IMPETUS FOR BASQUE FEMALE MIGRATION TO AMERICA $\ldots \ldots \ldots \ldots \ldots \ldots \ldots \ldots \ldots \ldots \ldots \ldots$

IV FROM 'SERVING GIRLS' TO ETXEKOANDREAK $\ldots \ldots 42$

V LIFE IN A BOARDING HOUSE: THE FIRST AMERICAN-BORN GENERATION REMEMBERS $\ldots \ldots \ldots \ldots 55$

SELECTED BIBLIOGRAPHY $\ldots \ldots \ldots \ldots \ldots \ldots \ldots \ldots \ldots \ldots$

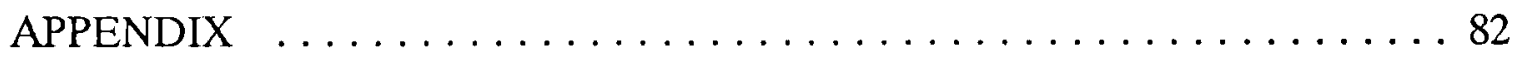




\section{LIST OF FIGURES}

FIGURE

1. Map of the Basque Country $\ldots \ldots \ldots \ldots \ldots \ldots \ldots \ldots \ldots \ldots$

2. Map of Harney County, Oregon $\ldots \ldots \ldots \ldots \ldots \ldots$ 


\section{CHAPTER I}

\section{HISTORICAL OVERVIEW OF EUZKADI (BASQUE COUNTRY): SCHOLARSHIP AND DEBATE}

The Basque region (Euzkadi) occupies the area of northcentral Spain and southwestern France along the coast of the Bay of Biscay. The four Spanish provinces and the three French departements are situated in the remote western-end of the Pyrenees Mountains (see Figure 1), with a current population estimate of about two and a half million people, of which approximately 27 percent or roughly 70,000 people speak Basque (Euzkera) today. ${ }^{1}$

It has been said that the Basques are easy to define geographically but impossible to account for historically. Often called the "mysterious" people of Europe, the dramatic aspects of their unresolved origin has been emphasized and sometimes exploited by scholars who have studied the Basques.

${ }^{1}$ Douglass, William A. "The Basques," Harvard Encyclopedia of American Ethnic Groups, Stephen Thermstrom, ed. (Cambridge: Harvard University Press, 1980): p. 173. Although with the Basque Nationalist movement and the death of Francisco Franco in 1975, aggressive efforts have been made toward providing accessible education in the Basque language to all children through the Ikastolak (Basque schools). Therefore, it is quite possible that the percentage of Basque speakers is higher today. 


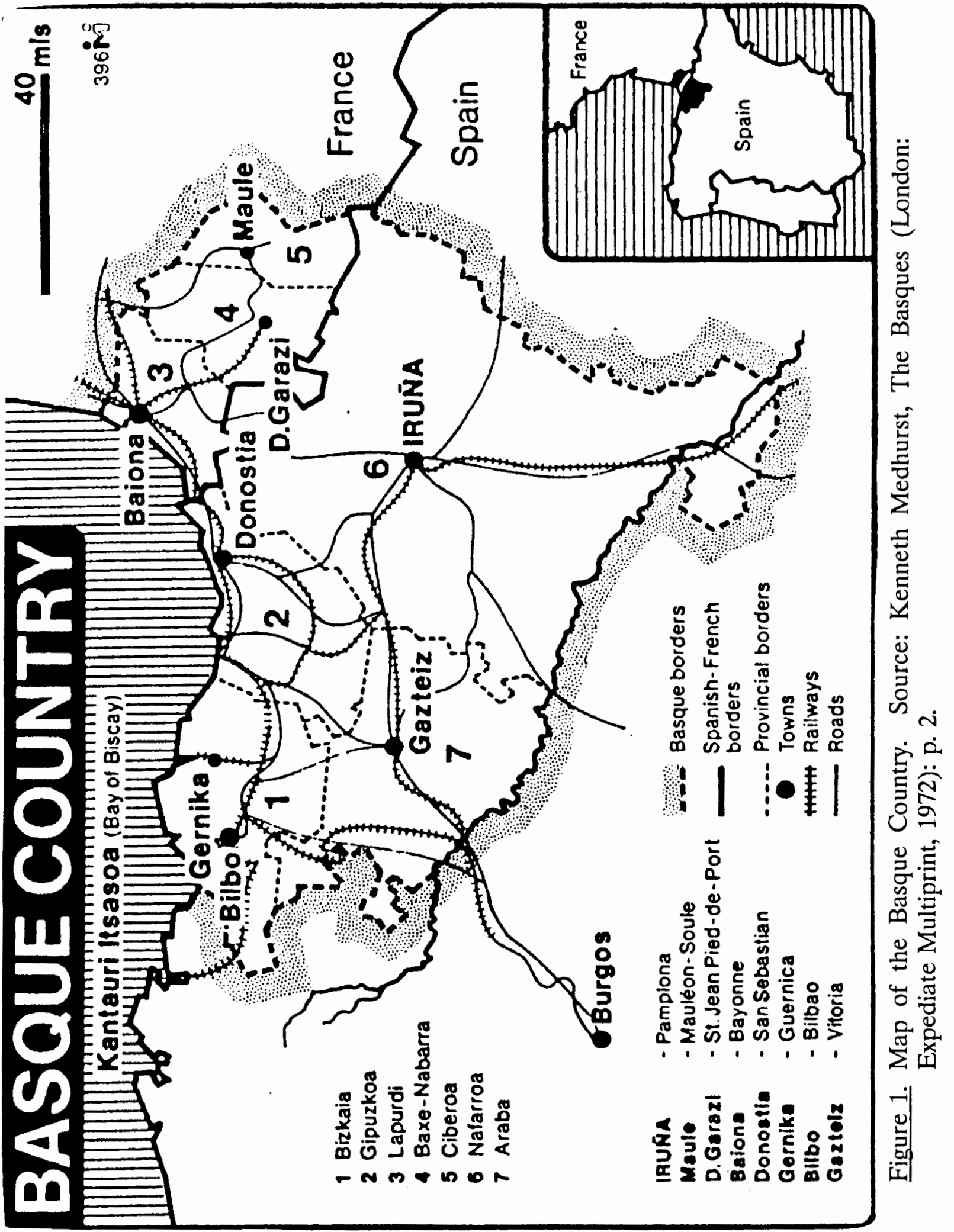


The constant focus on origin has created many theories and set the stage for perpetual debate. $^{2}$

According to Rodney Gallop, three general characteristics of the Basque vocabulary include: the lack of abstract words, the lack of collective terms, and the extensive use of onomatopoeics. ${ }^{3}$ They call themselves Euskaldunak, meaning speakers of Basque, supporting the importance placed on their language; which to this day remains a linguistic puzzle. Roger Collins, in a recent history of the Basques asserts that the "peculiarity of the language is such that it has so far defied acceptable classification. . . . Indeed the linguistic analysis of Basque remains a peculiarly controversial field of endeavour."1

${ }^{2}$ Eiguren, Joe. The Basque History: Past and Present (Boise: The Offset Printer, 1972): p. 19. In this study Eiguren cites the linguistic theory advanced by historian Bosch Gimpera which supports the notion that the Basques are descendants of the palaeolithic Iberians. In this theory, Gimpera stresses that in the Basque language nearly all the names for sharp instruments and tools are derived from the word, aitz, which means stone. For example: aitz-aga: lance aitz-ortiz: fork aitz-urr: hoe aitztto: knife aitz-kor: axe aitz-tlurr: scissors.

${ }^{3}$ Gallop, Rodney. A Book of the Basques (Reno: University of Nevada Press, 1970, Original Edition, London: MacMillan, 1930): p. 135. Gallop uses these examples or characteristics of the Basque language as evidence of its antiquity but instead of describing the language as old he uses the phrase "primitive mentality" in his discussion. Gallop looks at Basque ethnicity and its symbols from an anthropological perspective and credits the Basque character, which he describes as "independent and gay, yet practical with a medieval-like somberness," as the main ingredient in Basque cultural continuity.

${ }^{4}$ Collins, Roger. The Basques (London: Blackwell, 1986): p. 9. Collins is a conscientious historian and has a broad acquaintance with sources on the Iberian Peninsula which makes his treatment of the Basques a success. Selective footnotes substitute for a full bibliography but abundant and high quality maps enhance the value of his work. There are differing opinions among Spanish historians regarding the Basque language. For instance, Salvador de Madariaga in Spain: A Modern 
Morton Levine wrote of the relationship between the Basque language and cultural isolationism and concluded that the Basques displayed "an unquenchable desire to remain Basque," and further suggested that Euzkera was the instrument used for self-identification and for the exclusion of non-Basques. ${ }^{5}$ Basque author, Joe Eiguren has written that the Basque language contains an extensive vocabulary of terms, many pejorative, to refer to non-Basques, hence the inherent presence among Basques of the concept of uniqueness and of a view of themselves as different from any other people. ${ }^{6}$ Basque ethnocentrism is really not unique as the same characteristics can be applied to any ethnic group. ${ }^{7}$

The survival of the Basques from as early as the Middle Palaeolithic Age-40,000 years ago is questioned by some historians but generally accepted as valid by most. Citing the Basque language and the unique blood type (an unusually high

History (New York: Praeger, 1958): p. 17, states: "Now it is evident that if Basque were the general language of Spain before her Romanization, the remnant of it is but a philological curiosity without much historical significance."

${ }^{5}$ Levine, Morton E. "The Basques" Natural History 76 (April, 1967): pp. 45-50. Also see Jeronima Echeverria, California-Ko Ostatuak: A History of California's Basque Hotels (PhD. Dissertation, North Texas State University, 1988): p. 9.

${ }^{6}$ Eiguren, Joe, op., cit., p. 14.

${ }^{7}$ Davydd Greenwood describes ethnicity as that part of the culture of a group that "accounts for its origin and character, thereby differentiating it from other groups within large-scale political units and setting the tone for its relationships with those groups and with the government...," in "Continuity and Change: Spanish Basque Ethnicity as a Historical Process," in Ethnic Conflict in the Western World, Milton J. Esman, ed. (Ithaca: Cornell University Press, 1977): p. 83. In this study there are fifteen essays by different authors who discuss ethnic conflict in diverse Western societies and in addition, four essays that examine the theoretical and historical sides of the phenomenon of ethnoregionalism. There are many useful references but the index is incomplete. 
incidence of type $\mathrm{O}$ and negative $\mathrm{Rh}$ factor $){ }^{8}$ which have endured more than a millennium of invasions as evidence, scholars have categorized the Basques as one of the oldest surviving cultures in Europe, intact essentially from prehistory. The serological evidence suggests that the Basque people have remained, "over a relatively long period of time, a small and somewhat isolated breeding population."'

The continuity of settlement remains unsupported because archaeological evidence is inconclusive. There has been some archaeological work done on the various prehistoric stages of human occupation of the western Pyrenees; for example, a few fragments of a single skull of a late Cro-Magnon man (c. 9000 BC) in the Basque region. Archaeologist Paul G. Bahn's prehistorical study on the French side of the Pyrenees suggests the dual nature of the mountain chain as both a barrier to communications and as a passage. The author cites historical records of contacts between the French and Spanish sides, principally in the context of transhumanance movements. Upland mousterian sites suggest an early beginning to such movements.

${ }^{8}$ Collins, Roger, op. cit., p. 5. Tests have been used to show that a disproportionately high percentage of Basques have blood of Group O, similarly, the blood Groups $\mathrm{B}$ and $\mathrm{AB}$ are proportionately even rarer amongst Basques than among other western Europeans. In addition, the occurrence of the Rhesus negative blood factor is more frequent among Basques than any population in the world.

${ }^{9}$ Douglass, William A. and Jon Bilbao. Amerikanuak; Basques in the New World (Reno: University of Nevada Press, 1975): p. 10. This impressive and monumental work begins with the history of the Basques in the Old World and continues with the migratory theme of Basque participation in Spain's 'Age of Discovery' and the later migration of Basques to North and South America in the late 1900s. The authors concentrate on Basque cultural continuity and cite many cohesive Basque communities throughout the New World. Extensive footnotes and bibliography are inclusive and contemporary. 
Herd following, and megalithic tombs and Iron Age tumuli show the pattern continuing into the first millennium $\mathrm{BC}$, when written historical records take over. ${ }^{10}$ But there has been nothing intrinsic to the material remains of the megalithic and cave cultures thus investigated which proves these to be the products of societies lineally related to the Basques. On the other hand, for later periods when documentary sources indicate that Basques were firmly settled in the region, there have been virtually no archaeological excavations conducted into the material culture of their society. ${ }^{11}$

The theories so far discussed have been used quite often to postulate the idea of a distinct Basque race, although some scholars, like the historian, Stanley Payne, discount this belief:

there is no scientific support to the concept of a Basque race. . their unity is based in language and culture rather than biology, even though they exhibit certain somewhat distinct physical characteristics. ${ }^{12}$

Basque history based on written documents begins with the work of Roman historians who comment on the imposition of Roman rule and occupation in northern

${ }^{10}$ Bahn, Paul G. Pyrenean Prehistory. A Palaeoeconomic Survey of the French Sites (London: Warminster, Aris and Phillips, 1984): pp. 35-37.

${ }^{11}$ Collins, Roger, op., cit., p. 8. Although Collins does not discuss or speculate on the reasons for the gap in the archaeological record, my conversations with various historians have yielded explanations based on political reasons and perhaps the lack of access to sites available for excavations.

${ }^{12}$ Payne, Stanley. Basque Nationalism (Reno: University of Nevada Press, 1975): p. 9. Payne's book is impressive in its historical context, that is, Spanish history, but he fails to alert his audience to the fundamental reasons behind Basque nationalism and its movement; that is, to maintain Basque identity and ethnicity in the form of political independence for Euzkadi. 
Iberia. Roman legions first entered Iberia in $218 \mathrm{BC}$ and by $133 \mathrm{BC}$ had defeated the Celts and established permanent settlements in Alava and Navarra, two Basque provinces. Roman historians make frequent references to a people living near what is now the Basque Country and speaking a peculiar language which their neighbors did not understand, explicitly noting the uniqueness of the population. Pompey established his winter quarters in Pamplona (hence the name, but called Iruna in Euzkera), suggesting that the Basques must have already been subject to Rome to some degree. ${ }^{13}$ Although the Basques were somewhat insulated from direct Roman control because of their geographical location, Rome's influence on them is nevertheless apparent. The Romans established a major road through the Pyrenees into France and constructed roads into mining areas in order to exploit the resources.

The Roman historian, Pliny the Elder, in his work Natural History, remarked:

Iron ore is found in the greatest abundance of all metals. In the coastal part of Biscaya washed by the Atlantic there is a very high mountain which, marvelous to relate, consists entirely of the metal. . . 14

It is likely that the process of complete Romanization of the Basques was interrupted in the third century $\mathrm{AD}$ by the invasion of Germanic people into the peninsula. Douglass and Bilbao explain that this could be why the Basque language did not entirely disappear as did other European tongues under Roman control. While these people did pass through the Basque region, they did not attempt to

${ }^{13}$ Gallop, Rodney, op., cit., p. 135.

${ }^{14}$ Pliny, Natural History, with an English translation (London: 1952): pp. 234-235. In William Douglass and Jon Bilbao, op., cit., p. 49. 
control it and instead headed for the Castilian meseta. Under constant pressure from the Goths, the Romans relinquished control of Iberia and southern France by 418 AD. The defeat of the Romans provided the Basques with a respite from outside interference as the Goths were less successful than the Romans in thwarting Basque military tactics.

In $711 \mathrm{AD}$, Arab forces crossed the Strait of Gibraltar into the Iberian peninsula and invaded the southern area of Rodericus, King of the Goths. The Arabs quickly consolidated their control over most of the peninsula and by 718 occupied Pamplona bringing them into contact with the Basques. Arab sources refer to the Basques as "primitive, fierce, and not to be trusted." ${ }^{15}$ Most of the references tell of battles in which the Basques maintained their independence by playing the Christians off against the Moslims. One of the most famous battles happened in 778 and is a good example of the conflict between historical sources on the Basques. Arab historian, S.M. Imamuddin, relates the event as following:

In 778 at Saragossa Charlemagne suffered a disastrous repulse at the hands of Husayh bin Yahya al-Ansari. Wittekind, the leader of the Saxons, rebelled in France and Charlemagne had to return to France without achieving anything. At the time of retreat ... The rearguard of Charlemagne was attacked and annihilated by the Basques in the defiles of Roncesvaux as it was passing through the Pyrenees. ${ }^{16}$

In one traditional Western Civilization text, Charlemagne's ill-fated quest is glossed over and made into a typical heroic tale:

${ }^{15}$ Imamuddin, S.M. A Political History of Muslim Spain (Pakistan: Najmah and Son, 1961): p. 42.

${ }^{16}$ Ibid, p. 42. 
Taking advantage of feuds among the Muslims in Spain, Charlemagne sought to extend Christendom southward ... In 778 he crossed the Pyrenees with indifferent success. As the Frankish army headed back north, it aroused the antagonism of the Christian Basques, who attacked its rear guard. In the melee the Frankish leader, a gallant count named Roland, was later enshrined in the great medieval epic, the Chanson de Roland. ${ }^{17}$

Douglass and Bilbao argue against this assumption and interpret the attack as evidence of the Basques' religious hostility toward Christianity. As emperor of the Holy Roman Empire, Charlemagne was the primary defender of the Christian faith. They also suggest the assault is proof that neither Christianity nor Islam were firmly entrenched in the region. ${ }^{18}$ There are some historians who have argued that Roland lost to a Basque force bent on avenging Charlemagne's sacking of Pamplona (Iruna). Others argue that the Basques and Arabs formed a coalition to inflict punishment on the Christian military leader.

Douglass and Bilbao also date the change from "fervent isolationism and the antecedents of the Basque migratory impulse" to the age of whaling, when the Basques moved out of the Bay of Biscay region in search of whales. ${ }^{19}$ It is impossible to date the beginning of Basque whaling due to the scarcity of documents and lack of archaeological work in Basque coastal areas. Recent archaeological discoveries on the south coast of Labrador include three Basque galleons from the

${ }^{17}$ Wallbank, T. Walter, et., al. Civilization Past and Present (Glenview: Scott, Foresman and Co., 1978): p. 191. The poem's status as a valid historical document has been criticized on the grounds of being overly mythologized, but it possibly contains one of the earliest written evidence of the Basque language.

${ }^{18}$ Douglass and Bilbao, op. cit, p. 44.

${ }^{19}$ Douglass and Bilbao, op. cit., p. 50. 
sixteenth century which are the oldest wrecks (from Europe) so far discovered in the New World north of Florida. This important work is the direct result of a ten-year, painstaking research project conducted by the Canadian historical geographer, Selma Huxley Barkham. She persuaded archaeologist James Tuck and Robert Grenier to excavate Red Bay, a small harbor on the coast of Labrador. According to the study, Basque shipbuilding and whaling methods were quite elaborate. Grenier states:

The prefabricated and self-supporting frames amid ships, which made for faster and stronger construction, forecast the technology of coming centuries. The carved keel, prodigal in use of labor and wood, looks back on a thousand years of tradition. ${ }^{20}$

The Basque whaling industry naturally led into another off-season venture-maritime commerce. There are reports of export trade from Basque ports by the end of the thirteenth century involving Castilian wool and Basque iron. By the end of the sixteenth century, commerce began to surpass whaling as the major coastal industry and Basque trade in the Atlantic grew to great proportions.

At the beginning of the sixteenth century Spain lacked sufficient population and economic resources to pursue colonialism on all fronts. Therefore, a militaristic policy of control, rather than a colonial policy of settlement was applied to the Mediterranean and the actual colonizing efforts were saved for the New World. ${ }^{21}$ Both policies depended on two elements--sea power and a supply of iron products.

${ }^{20}$ Grenier, Robert. "Excavating a 400-Year Old Basque Galleon," in National Geographic, 168, No. 1 (July 1985): pp. 62-63.

${ }^{21}$ Lynch, John. Spain Under the Hapsburgs: Empire and Absolutism Vol. I (New York: Oxford University Press, 1964): p. 29. 
Without both military and commercial maritime transportation, Spain could not hope to unite her Old World holdings or develop her New World territories. Efforts to colonize required reliable supplies of iron implements and military campaigns consumed large amounts of weaponry. Castilla lacked sufficient quantities of both necessities, whereas maritime activities and the mining and manufacture of iron constituted two major sources in the economy of the Basque Country. In her autobiography, They Shall Not Pass, Dolores Ibarruri begins Part One with the title, "In the Beginning there was Mineral ..." Her economic theory of Spanish exploitation in the Basque Country is based on the extraordinary richness of its minerals. She states:

while the best foreign ores had a metallic yield of 48 per cent, the ores of Vizcaya reached a yield of 56 per cent and more of iron. Appreciating the importance of the Basque ore for the national economy, a famous Spanish playwright of the 16th century, Tirso de Molina, wrote: "Thanks to Vizcaya's iron/ Spain can conserve her gold ..."'22

For the Basque economy the opening of the New World was an immediate stimulant. Both the metal products of the Basque factories as well as the vessels produced in Basque shipyards were in great demand. In 1498, Queen Isabella offered to subsidize construction of ships larger than 600 tons and in 1502 she offered Basque shipbuilders 50,000 maravedis, plus guaranteed cargo for six months, for each vessel larger than 1500 tons. $^{23}$

${ }^{22}$ Ibarruri, Dolores. They Shall Not Pass (New York: International Publishers Company, 1966): p. 12.

${ }^{23}$ Douglass and Bilbao, op., cit., p. 68. 
In 1503 , the Spanish monarchs conceded to Sevilla a monopoly of New World trade to be administered by the crown officials of the Casa de Contratacion. However, Andalusian shipping was so underdeveloped and inadequate that by 1505 the Casa named a representative in Bilbao to recruit vessels and men for the American run. Douglass and Bilbao state:

... at the beginning of the sixteenth century Bilbao surpassed either Sevilla or Cadiz in maritime strength. The city possessed about five hundred vessels ... The shells and masts of most Andalusian vessels were constructed in the Basque Country. ${ }^{24}$

Many Basques joined the mercenary and missionary forces of the Spanish conquistadores in nearly all areas of Latin America and some, with their long history of maritime experience, continued to explore further lands for the Spanish crown. During the period of Iberian dominance of both European and New World history the Basques, as masterful seafarers and producers of metals and ships, enjoyed a large measure of political independence under the system of local fueros in Spain and fors in France. While it is not the initial phase of Basque migration to the New World that is the focus of this study, the Basque participation in Spain's "Age of Discovery" is significant in that it shows the long history of the Basque migratory tradition to the New World.

It is at this juncture that Basque history begins to focus on the New World, for in the Old World the age-old autonomy of the Basques came to an abrupt end with the decline of Spain. On the losing side of the Carlist Wars during the nineteenth

${ }^{24}$ Ibid, p. 69. 
century, the Basques formally lost their traditional rights and liberties granted by the fureros and military conscription was enforced for the first time. The French Revolution had earlier stripped the French Basques of their fors in the name of national unity, and the French Basques continue today as subsistence farmers and herders with their only industry being tourism. On the other hand, the Spanish Basques, by the turn of the century were awakened to the birth of Basque Nationalism by a leader named Sabino de Arana y Goiri. ${ }^{25}$ This rejuvenated an even greater desire among many Basques to retain their cultural traditions, rights and especially their language, and also created a climate of political oppression manifesting itself in forced migration for some. In her study, Jeronima Echeverria states that "evasion of military service was widespread among both Spanish and French Basques in the nineteenth century and became acute during World War I."26 It has been said that the ability to adapt may be the clue to Basque survival:

They have accommodated when they could, fought when they had to, and stood aloof within their ethnic consciousness, mountain fastness, and stone wall of a language to survive invasion and occupation. ${ }^{27}$

${ }^{25}$ Sabino Arana began to devote himself entirely to Basque studies in 1885 , by first learning the language (since most upper-middle class Bizkaian families, as the Aranas, spoke only Castilian). In 1892 Arana published the framework for Basque independence in his book Bizkaya Por Su Independcia. In 1893 Arana made a public statement announcing his intentions to form a political movement dedicated to Basque independence. See Stanley Payne, op. cit., pp. 69-71.

${ }^{26}$ Echeverria, Jeronima, op., cit., p. 16.

${ }^{27}$ Esplund, Kandace and Fred Nelson. "Basques in the West," in Sunset, (June) 1976: p. 63. 
Adaptation could very well explain why the Basque culture has also survived in the Pacific Northwest but it does not define how this process evolved. The focus of this particular study is to examine that process through the eyes of Basque immigrant women and the institution they helped to create and manage: the Basque boarding house (Ostatua). These establishments will be discussed in the following chapter within the context of the fluctuating sheep industry, which played a crucial role in the initial migration of Basques to Eastern Oregon. Beginning the discussion is a summary of conditions in Europe, especially Spain, and the special circumstances regarding Basque inheritance laws both of which helped reinforce the necessity for migration from Europe. 


\section{CHAPTER II}

\section{THE SHEEP INDUSTRY AND BASQUE IMMIGRATION TO HARNEY COUNTY, OREGON}

During the nineteenth century, most European societies were experiencing farreaching economic and social changes. The most significant of these changes was a rapid increase in population. In Europe the population increased from an estimated 140 million in 1750 to 400 million in 1914, not including an additional 35 million (and their descendants) who emigrated during those years. ${ }^{1}$ Food production also increased, but not as rapidly as did the population, thereby setting large numbers of people in motion. The year 1900 is significant in Spanish demography: an excessive death-rate--nearly twice that of the European average--began to abate significantly. Between 1900 and 1930, the population rose from 18 to nearly 24 million--a process which was accelerated after 1930 by a dramatic decline in infant mortality. This increase could not be supported by an already over-populated countryside; therefore, people found their way either to America or to the cities. ${ }^{2}$

1 Seller, Maxine Schwartz, ed. Immigrant Women (Philadelphia: Temple University Press, 1981): p. 16.

${ }^{2}$ Carr, Raymond. Spain, 1809-1939 (London: Oxford University Press, 1966): p. 413. 
Stanley Brandes uses the Basques as an example of "institutional migration" which is inherent in and the supporter of traditional socioeconomic relationships, and thus is necessary for the maintenance of that social order. The Basques, he states:

have had to maintain a delicate man-land ratio, which has precluded the division of farmsteads among heirs. One child inherits the farmstead, marries, and lives on with the aging parents. The siblings marry heirs to other farmsteads, live on singly with the heir, or migrate. Here, migration is a built-in economic safety valve for the perpetuation of the established order. ${ }^{3}$

This discussion omits those individuals from the coastal and industrial areas of Euzkadi who chose to migrate because of other factors, many of which were largely political. The suppression of the Basques by the Spanish government was, by the nineteenth century, systematic. All civil servants had to be of Spanish descent and it was a crime to speak Basque. This was the result of their defeat in the Second Carlist War in 1876, in which Basques were obliged for the first time to serve in the military. Thus, for many Basques, demographic factors, inheritance customs, the lack of opportunity for advancement and the threat of military conscription were major reasons for their migration at the turn of the century. ${ }^{4}$

${ }^{3}$ Brandes, Stanley. Migration, Kinship, and Community: Tradition and Transition in a Spanish Village (New York: Academic Press, 1975): p. 14. Brandes cites William A. Douglass, Death in Murelaga: Funerary Ritual in a Spanish Basque Village (Seattle: University of Washington Press, 1969) as his source on Basque socioeconomic traditions.

${ }^{4}$ Echeverria, Jeronima, op. cit., p. 15. In her study Echeverria states that official lists indicate that 18,547 young Spanish Basque men left Euzkadi between 1911 and 1915. In Douglass and Bilbao, op. cit., p. 129. 
The nascent South American sheep industry, however, represented a critical element in the migration process for Basques. The initial South American phase was succeeded by movement to the American West. According to William Douglass, by the 1830s Basques were established as the major ethnic group in the sheep industry of the Argentine Pampas. The California Gold Rush spurred further Basque migration into North America. California, with its inflated market for meat products in the nearby mining camps, offered these experienced herders an opportunity to exploit their knowledge of livestock. ${ }^{5}$

Likewise, the mining booms of the 1860 s in the Owyhee region of eastern Oregon helped create a market for livestock and similarly attracted migrant herders. Children of Oregon trail pioneers, surrounded by expensive lands in the western Oregon valleys, flowed east over the Cascades to take advantage of the Homestead Act of 1862. The migration of people and livestock accelerated in the 1870 s with settlers, cowboys and managers, hired by outside investors, all scrambling for control of the Harney Basin (see Figure 2). In the 1880s, false surveys, bribery and coercion prevailed as owners of large herds sought to gain a monopoly over fertile pasture and water resources. ${ }^{6}$ The stage was set for conflict between the itinerant sheep raisers,

${ }^{5}$ Douglass, William and Richard Lane. Basque Sheepmen of the American West (Reno: University of Nevada Press, 1986): p. 4.

${ }^{6}$ U.S. Department of Interior, Bureau of Land Management, Taylor Grazing Act in Oregon, 1934-1984 (Washington D.C., 1984): p. 5. Also see Giles French, Cattle Country of Peter French (Portland: Binford and Mort, 1964): p. 11, who says; "of the four big stockmen who achieved the most prominence [in southeastern Oregon] and made the most history, all came from California; all were backed by financiers in that state. Without available money they could not have expanded to become the land 
many of whom were Basque, and the cattle ranchers and homesteaders. In 1908, the local newspaper ran an article titled, "Basques Crowding Home Sheep" stating that "Prominent wool growers of the Stein's [sic] mountain region are complaining of range conditions ... claiming that foreign sheep are eating out their range and pay no taxes in Harney County." The somewhat ridiculous article goes on to blame "foreign sheep" for the problem, not the foreign sheepowners, and declares with dignity, "Harney County grass for Harney County stock."7 Many of the Basques who migrated to Oregon had never tended a herd of sheep in their lives, but the most accessible opportunities for advancement were within the confines of this particular industry. ${ }^{8}$

In the semi-arid, high desert region of Malheur and Harney counties the soil supports a variety of grasses necessary for sheep grazing. The water supply from creeks and small lakes is sufficient, the climate is dry and the location is remote from population centers detrimental to sheep raising. There are two hundred and seventy

and cattle barons they did."

7 The Times Herald (later changed to The Burns Times Herald), "Basques Crowding Home Sheep," August 20, 1908, p. 3, col. 4.

${ }^{8}$ Eiguren, Joe. Kashpar (Caldwell: Caxton Printers, 1988). See for an intimate account of a Basque migrant from the coastal town of Lekeitio, Bizkaia, who despised the sheepherding business but had to endure the lonely and harsh life in order to help a widowed mother. On the other hand, there were herders who liked the job. Santos Arguinchona, "Shorty", also known as an excellent camp tender and cook (as a child I loved going to the sheep camp to eat Shorty's earthen-baked bread, dipped in his delicious beans), testified in an interview that he did not mind the life of a sheepherder, "I like it, the mountain life because if you do your job good and nobody boss you. Nobody fool you around." Interview with Royal Jackson, September 24, 1976, Burns, Oregon. 


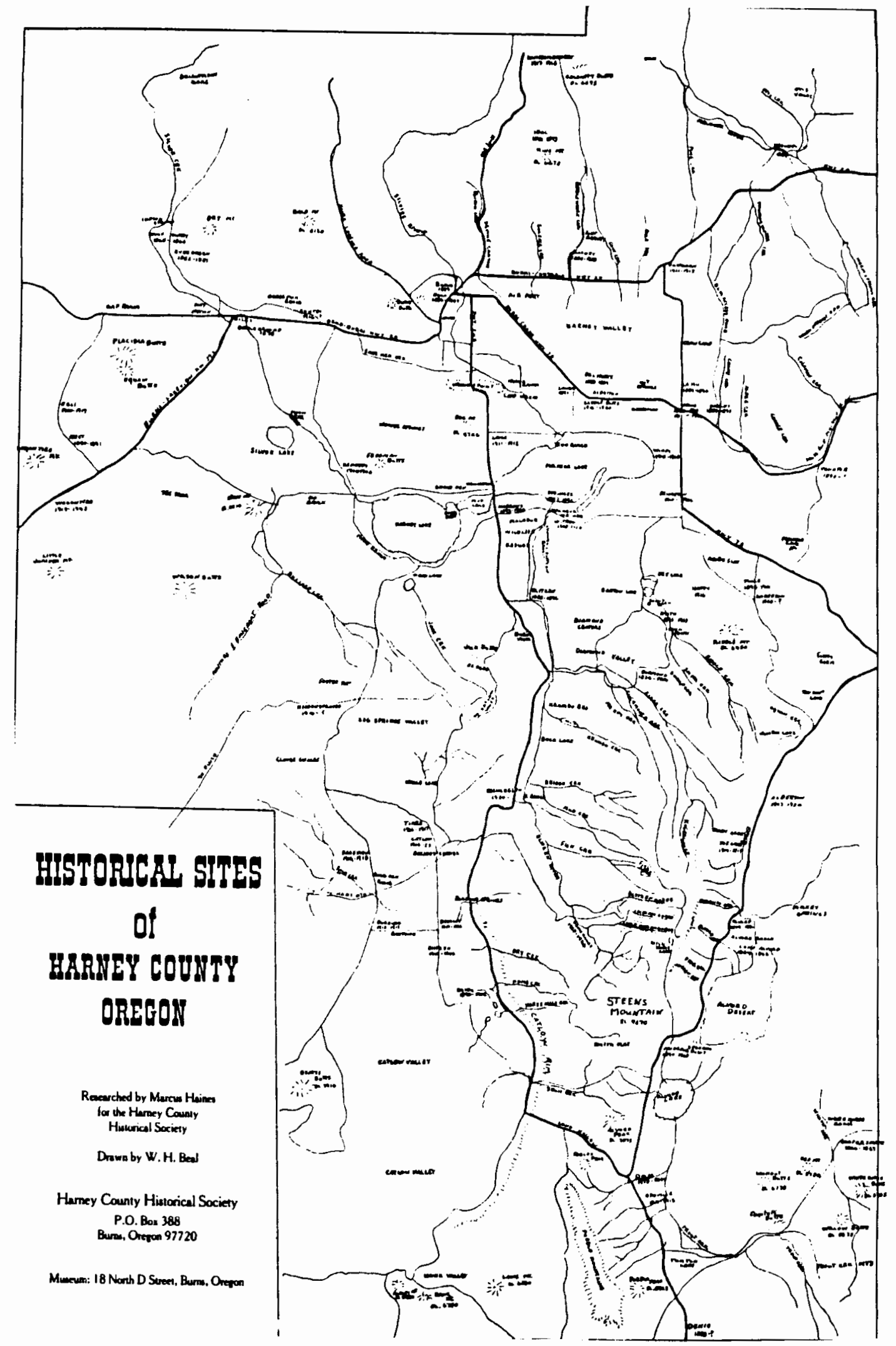

Figure 2. Map of Harney County, Oregon. 
five miles of open country between Crane, Oregon and Winnemucca, Nevada, furnishing a wide range ideal for the sheep industry to flourish. ${ }^{9}$

The method of settlement for Basque herders was similar throughout the American West. Basque men would take bands of sheep, owned by someone else, into the hills. They remained for years, until accumulated wages enabled them to buy flocks of their own. Friends from the Old Country would then be coaxed to come and relatives sent for. Partnerships between experienced herders were often formed, thus providing the sufficient capital to purchase range and more sheep. Each fall when the lambs were shipped to market, two bands of ewes were consolidated into a single unit and the excess herders were laid off until the following spring lambing (this was before the three-year contract system which insured yearly employment). ${ }^{10}$

Near the turn of the century, Congress legislated a national forest and park system whereby access to grazing on national forest land was to be determined by an allotment system under which local boards, comprised of settled ranchers, made the allocations. In order to qualify for a permit an individual had to be a United States citizen and own land. Many mountain ranges, such as that in Harney County in Oregon, were too thinly forested to qualify for inclusion in the national forest scheme, yet were sufficiently alpine to support summer grazing. After decades of unregulated and competitive use of these lands, an ecological crisis resulted. Erosion, depletion

${ }^{9}$ Harkness, Ione B. "Basque Settlement in Oregon" in Oregon Historical Quarterly 34 (1933): p. 273.

${ }^{10}$ Ibid, p. 274. 
of water resources, growth of brush and poisonous plants, as well as years of conflict between competing user groups, all contributed to the crisis. ${ }^{11}$

The Taylor Grazing Act of 1934 (named for Representative Edward Taylor of Colorado) was one of a series of reform measures passed during the New Deal. It was a vehicle for withdrawing an initial 80 million acres from future filing or transfer to state or private interest. By 1936, this had been expanded to 142 million acres in eleven western states. The Taylor Act gave preference for grazing permits to "such bona fide settlers, residents, and other stock owners" who owned adjacent or nearby lands or water rights. ${ }^{12}$

In early 1936, Oregon was established as a separate region within the Act's provisions and Marvin Klemme from Oklahoma was named to head the operation. Meetings were called to discuss the issue of grazing and qualification for permits. In a series of letters to the Bums Times Herald, Felix Urizar accused Klemme and others of unjust treatment toward the Basque sheepmen, like himself, and called them racist in their attitude. The primary objection voiced in the letters was the application of the word "transient" to Basque sheepmen. According to an author of a grazing report about Harney County, the term "transient" was

applied to sheepmen who come in from outside districts, own no land in Steen's Mountain and may, or may not, own land elsewhere. It may

11 Calef, Wesley. Private Grazing and Public Lands, Studies of Local Land Management of the Taylor Grazing Act (Chicago: University of Chicago Press, 1960): p. 6.

12 Ibid, p. 10. 
be taken as a fact that Basque sheepmen, generally, do not own land anywhere. ${ }^{13}$

In a letter published in the November 17, 1937 issue of the Burns Times Herald, Urizar listed the amount of capital lost and names of long-time Basque residents who left Harney County as a result of the Taylor Grazing Act:

On today's stage from the Star Hotel Teles Zabala, Joe Zarraonandia and Tomas Zabala left Burns. Joe Abasolo left last week.

They left Harney County seeking a new location to live and run sheep, as they have been driven out of Harney County by Mr. Klemme and his unjust administration of the Taylor Act.

Teles Zabala has been in Harney Country for 33 years; Joe Zarraonandia for almost 20 years and Tomas Zabala for 19 years . . . Joe Abasolo has been in Harney County 21 years and has run sheep nearly all this time.

These seven men took out of Harney County, at least $\$ 125,000.00$ in money, personal property and livestock. In their sheep operations they spent in Harney County a good many dollars which they produced themselves. ${ }^{14}$

${ }^{13}$ Douglas and Bilbao, op. cit., p. 294. This official government report is misleading and contradictory to an article published decades earlier in The Times Herald, January 26, 1918, p. 8, col. 3, reporting that "Elilis [sic] Ramirez, one of the extensive sheep men of the southern part if this county and Nevada, was in town yesterday on business. He and his brother are wintering some 9,000 head of sheep in the vicinity of Jack Mountain." In Figure 2, Jack Mountain is named Jack Butte, but many local residents refer to the site as Jack Mountain. This article lends substantial evidence of the importance given to immigrant sheepmen (and their valuable dollars) within the local business community, long before the passage of the Taylor Grazing Act.

${ }^{14}$ Urizar, Felix. The Burns Times Herald, November 17, 1937, p. 4, Col. 1 and 2. 
By 1937 the Harney County tax assessor complained that sheep numbers on Steens Mountain had dropped to ninety-one thousand, damaging severely the local economy. ${ }^{15}$

Viewed from the perspective of the Basque ethnic group in Burns, the Taylor Grazing Act was a major event. Even today, the Basques tend to view "time" in terms of before and after "Taylor Grazing." It is clear from the evidence that the Taylor Grazing Act skillfully destroyed the livelihood of the itinerant Basque sheepman on the basis of his alien citizenship and non-ownership of land.

Coupled with the Taylor Grazing Act were the new immigration quotas (1924, Native Origins Act) setting the number of immigrants entering the United States yearly from eastern and southern Europe at very low levels. Various reasons were used to justify the quota deficiency between the so-called "new immigrant" and the older, Anglo-Saxon immigrant, but the main ingredient would have to be the increasingly xenophobic nature of American society. These newcomers did not speak English, could very well be socialist, or even Marxist, and a large number of them were Catholic or Jewish. ${ }^{16}$

${ }^{15}$ Douglass and Bilbao, op. cit., p. 294.

${ }^{16}$ Zinn, Howard. A People's History of the United States (New York: Harper and Row, 1980): p. 373. Zinn states; "Congress, in the twenties, put an end to the dangerous, turbulent flood of immigrants (14 million between 1900 and 1920) by passing laws setting immigration quotas: the quotas favored Anglo-Saxons, kept out black and yellow people, limited severely the coming of Latins, Slavs, Jews. No African country could send more than 100 people; 100 was the limit for China, for Bulgaria, for Palestine; 34,007 could come from England or Northern Ireland, but only 3,845 from Italy; 51,227 from Germany, but only 124 from Lithuania; 28,567 from the Irish Free State, but only 2,248 from Russia." 
On November 11, 1926 an article appeared in the Burns Times Herald relating

the quota system to the Basques:

After a wait of many months for permission to enter the United States as a non-quota immigrant, Mrs. Marcelino Osa and two children have arrived at Burns. Had a non-quota classification not been possible it would have been several years before Mrs. Osa could come to the United States. The annual quota from Spain under present laws permits but 200 immigrants a year. There are several thousand applications on file. ${ }^{17}$

Ironically, the Act created the foundation for a new relationship between the Basques and their neighbors. By the 1940 s, sheepherders were in such short supply in the West that political maneuverings were set in motion in Washington. Sheep ranchers succeeded in their lobbying effort to make Basques desirable immigrants who should be accorded special treatment by immigration policy. The public image of the Basque changed during this period, as popular literature began to depict the Basque herder as a romantic and heroic figure. ${ }^{18}$ The Sheepherder Laws (as they

${ }^{17}$ Burns Times Herald, "Wife, Children Arrive From Home in Spain," November 11, 1926, p. 4, col. 1. The non-quota status was the defense used by the Osa's attorney due to the fact that Margarita had lived, worked, married and given birth to their first child, Paquita, in Boise, Idaho. In 1920, she became ill with typhoid fever during the early stages of her second pregnancy and returned to Ondarroa to recuperate. Marcelino Osa, Jr. was born in the Basque Country.

${ }^{18}$ Etulain, Richard. "The Basques in Western North American Literature," in William Douglass, et al, eds., Anglo-American Contributions to Basque Studies (Reno: Desert Research Institute, Reno, 1977): p. 15. See also, George Francis Brimlow, Harney County, Oregon, and its Range Land (Portland: Binford and Mort, 1951): pp. 208-209, who talks of the Basques: "Meanwhile, on the fringes of range land, had come the Basques, as sheepherders...The 'Bascos,' reluctant at first to be face to face with cattlemen...forged ahead... They led no dull life. They tended their ranches well, played well and ate well. Not to be cast off were the hereditary recipes and customs of long ago. After their coming into eastern Oregon..., they labored hard. Their holdings became fruitful and profitable. The girls, artistically inclined in decorating, 
were often called) of the 1940s and the special exemptions failed to alleviate the growing labor crisis in the sheep industry. Sheepmen continued to pressure their representatives for substantial legislation. In 1950, a bill sponsored by Senator Patrick McCarran of Nevada, passed the Senate as Public Law 587. It permitted 250 Basque herders into the country. In 1952, Public Law 307 allowed an additional 500 herders into the United States. ${ }^{19}$

By 1965, the young men of the Basque Country were less enthusiastic at the prospect of signing a sheepherder contract. The growing disenchantment with sheepherding was reinforced by the press in the Basque Country. In 1969, the newspaper, La Voz de España (San Sebastián), published an article titled, "Odyssey of Our Basque Sheepherders in America," with the subtitle, "A Seductive Adventure Which Quickly Becomes the Reality of a Hard Life in Constant Solitude." Similarly, El Correo Español (Bilbao) in 1971, featured articles documenting the declining interest in sheepherding. One of the articles, titled, "Only One of Every Hundred Basque Herders in the United States Makes his Fortune," ${ }^{120}$ must have discouraged

kept homes of stability and cheer for their husbands."

Considering the education system in Spain for females, which concentrated on facilitating young women to be proficient in the art of traditional cooking and of intricate handwork (knitting, embroidery, etc.) rather than in other educational areas, it not unusual for Brimlow to have mentioned the charming homes created by these women.

${ }^{19}$ Douglass and Bilbao, op. cit., p. 311.

${ }^{20}$ Ibid, pp. 322-323. 
an unknown number of would-be immigrants. The improved economic conditions in Europe also served to hamper the recruitment of Basque sheepherders.

By the spring of 1975 , the last of the range sheep were rounded up and sold by their owner Don Miller of Burns. ${ }^{21}$ This sale signaled the end of an era both for Harney County and also the Basque social institution, the boarding house, which had begun to appear in Burns in the 1920s to accommodate and serve the growing population of herders.

The boarding houses became the principal means for the maintenance of Basque cultural identity by providing a locus for the practice of the traditional Basque language and customs. The establishments were purchased by former herders who had acquired enough English and familiarity with American ways to serve as agents for the remaining herders in the larger American society and by their wives, the etxekoandreak, who managed and maintained the businesses.

An excerpt from an oral autobiography by the late George Hibbard, whose father was a dentist in Burns, describes the role of the etxekojaun (Basque male head of household) quite vividly:

Next I want to tell you about the Basque, or as we used to call them, Baskos. And my father formed a friendship with one Basque here named Blackie Osa. His name is Marcelino but that's the name of his son also, and they had the ... what is now the Plaza Hotel. But this Blackie Osa would not only send patients to my father, he would bring them. And then he would stand by them ... the chair, and translate

21 Arguinchona, Santos. Interview with Royal Jackson, September 24, 1976, Burns, Oregon. There does exist today, two large sheep operations in Harney County consisting of 2,000 head of sheep per owner, neither of whom are Basque. Herders are now imported from areas in Latin America, such as Peru. 
for them. He would ask my father, he said, "Fix up their mouth, whatever it needs, and whatever you do, use all the gold you can in front, and don't ever remove the four front teeth, unless it is necessary." Well my father, being logical knew why, but I didn't. And it's because they use their front teeth in pulling the testicles from the lamb. And this of course is not done anymore, but it was one of the ways they were different from the local people. And of course these were considered a great delicacy, the testicles I mean. And were called Rocky Mountain oysters. $^{22}$

The preparation and serving of such delicacies was only part of the responsibility of the Basque women. The women (etxekoandreak) who owned and managed the boarding houses were depended on for the daily marketing, cleaning, cooking, and the creative bookkeeping necessary for the success of the business. These women, their reasons for migrating to the American West, and their multiple roles as proprietors, wives and mothers, and citizens of the larger Burns community will be examined and discussed in the subsequent chapters. By utilizing the oral histories of these women, their families, boarders and non-Basque participants, the following chapters contain primary historical evidence demonstrating the importance of the etxekoandreak and their ostatuak (boarding houses) for the continuation and endurance of Basque cultural ethnicity in an American community. 
CHAPTER III

\section{THE BASQUE BOARDING HOUSES (OSTATUAK): AN IMPETUS FOR BASQUE FEMALE MIGRATION TO AMERICA}

Boarding with families was an adaptation of the Old World traditional extended family model to a situation in which immigrants, who were usually young, confused and with limited resources, could satisfy their need for socialization into the ways of the larger American community. The familial setting was an attractive and economically feasible solution to the newcomer, even more so when s/he had origin, ethnicity, occupation or kinship in common with the family.

In time, immigrant groups, such as the Basques, developed their own channels of communication about employment opportunities to ensure a steady labor supply. These information networks transmitted news about living arrangements. In turn, boarding situations kept information flowing and helped with the adjustment process. Immigrants found homes for their friends and relatives from the old country through the people they worked with; they found jobs through the people they lived with. Boarding with fellow immigrants, they could eat familiar foods and speak their own language. 
As the intra-continental Basque boarding hotels/houses were established, (most notably Valentine Aguirre's in New York) ${ }^{1}$, in San Francisco, Reno, Boise and later Burns, a "domestic" labor market for young, single Basque women developed. By utilizing the same kinship-regional communication routes already in place due to the sheep industry, young Basque women from Euzkadi were recognized as a natural supply for this burgeoning market. Basque women were accustomed to hard work and to having an economic role within the family, thereby facilitating the adaptation of their American work patterns from those they had known in the old country. ${ }^{2}$

The process for acquiring this needed labor supply parallelled somewhat that of the sheep industry. Advertisements would be placed in the Basque country for young women willing to work under contract for a boarding house in the United States, passage paid by the employer and to be repaid by the woman later through

${ }^{1}$ The Aguirre Hotel in New York is one of the oldest, built in 1910. Aside from owning the hotel, Aguirre and his sons served as agents, meeting every boat entering New York from Spain. All of the Basque immigrant informants were met by one of the Aguirres, fed, labeled, and sent on the correct train west. In other studies, such as Amerikanuak, and in oral history collections, Valentine Aguirre and his hotel are nearly always mentioned.

${ }^{2}$ All female informants (aged 60-92), tell of leaving the house by the average age of thirteen to perform domestic or factory labor in order to supplement the family income in Spain and this usually led to the end of their formal education. This theme is vividly illustrated by an article written by Jose Zapiain Irastorza titled, "Mujeres Vascongadas," in Vida Vasca (Bilbao and Vitoria, 1958): p. 113. In a flowery style, Irastorza emphasizes the vital economic contribution of the Basque woman to the household and the community whether it be in a fishing, agricultural, or industrial setting. While repeatedly praising their "feminine" qualities, the author, nonetheless centers on the unusual physical strength of Basque women and their capacity for hard work. 
wages. Personal communication also played a part in the enticement of Basque women from their homeland when letters arrived from friends and relatives expounding the wonders of the United States. ${ }^{3}$ While this and other studies reveal a diversity in the background of women interviewed (from fishing villages, farmsteads and mining areas), most were young, poor or close to it. Some came to join family members, but a sizable majority came alone. Between July 1, 1910, and June 30, 1915, over half a million unmarried, non-English speaking women immigrated from Europe, most of them under twenty-one years of age. ${ }^{4}$ Many of these women came to the United States on their own initiative, independent of, and sometimes in opposition to, the wishes of their families. At ninety-two years of age, Mrs. Osa vividly reveals the image of her mother crying at the port in Bilbao when she left for the United States in $1918 .^{5}$

${ }^{3}$ Osa, Margarita. Interview with author. March 17, 1986, Boise, Idaho. Mrs. Osa had no immediate family residing in the United States and tells of letters from a childhood girlfriend living in Boise who prompted her desire for adventure and a new experience from what she had known. In retrospect she later states, "if I had known how hard I would have to work, I never come to this place." Mrs. Cecilia Urizar talks of how nice the boat trip was, "We had lots of fun...that was the first time I was by myself...I was free then." Interview with Royal Jackson and Jennifer Lee, August 31, 1976, Burns, Oregon and interview with author, January 28, 1989, Burns, Oregon.

${ }^{4}$ Seller, Maxine Swartz, op. cit., p. 21. In my research, nearly all of the women who migrated, did so alone and in their late teens. Often freedom and a sense of adventure were their motives as well as more pragmatic reasons. For example, Mrs. Cecila Urizar was one of twelve siblings living on a small family baserria (farm) in the tiny village of Ispastar, Bizkaia. An older sister had migrated to the American West earlier and encouraged Cecila to do the same knowing the limitations inherent in the socio/economic system.

${ }^{5}$ Osa, Margarita, op. cit. 
According to an article by Thelma Kaplan,

In Spain as elsewhere women were exploited by two institutions--the Church and the family. But however exploitive the family and church may have been, these institutions provided women with a sense of stability, status and dignity. From the family women received protection, some degree of security, and the experience of cooperative activity. The Catholic Church was more than a place to pray to God and the Saints. It was a gathering place where women could reassert female community norms through gossip and commiseration. ${ }^{6}$

A distinction must be made here, however, between Spanish and Basque customs. In the traditional Basque culture, the religious institution of the Serora, is an example of the syncretic retention of indigenous rituals and Christianity. Roslyn Frank examined the remote, but continuously surviving Serora and concluded that the institution "clearly demonstrates the high status traditionally afforded the female in Basque society." She goes on to say that the Serora "is a woman . . . whose duties and privileges are the activities which, in the rest of Catholic Europe, have been traditionally assigned to men. ${ }^{7}$ These duties and privileges were condemned by the Church and forced many ancient Serorak into seclusion or led them to the stake, especially during the Inquisition. The function which most angered the male dominated hierarchy was the actual presence of a women on the altar, performing the necessary rituals (usually assigned to men) which accompany the celebration of

${ }^{6}$ Kaplan, Thelma. "Women and Spanish Anarchism," in Becoming Visible: Women in European History, edited by Renate Bridenthal and Claudia Koonz, (Boston: Houghton Mifflin, 1977): pp. 400-420.

${ }^{7}$ Frank, Roslyn M. "The religious Role of the Women in Basque Culture," in Anglo-American Contributions to Basque Studies: Essays in Honor of Jon Bilbao, edited by William A. Douglass and Richard Etulain and John H. Jacobsen, Jr. (Reno: Desert Research Institute Publication on the Social Sciences, 1977): pp. 153-60. 
Mass. The manifestation of this ancient institution is the role of the parish priest's housekeeper, which many Basque women perform both in the Old Country and New. ${ }^{8}$

Autobiographies of immigrant women also suggest that women who came to the United States on their own initiative may have been less strongly committed than other women to traditional roles. Others came because they preferred the freedom and independence of even poorly paid work in the United States to the dependence and constraints of the family and church. For them, immigration was a rejection, conscious or unconscious, of traditional female roles. ${ }^{9}$ Mrs. Osa shows this rejection in her biographical narrative. At the age of fourteen she was employed as a governess for a rich Spanish family living in Bilbao who had one child, only two years younger than Margarita. Margarita's duties were to dress and accompany the girl to school, dance classes, parties and the park. While having to look older in order to secure the position she held, Margarita had easily found a boyfriend who worked for a bank in Bilbao. In her own words she describes the social constraints forced upon her as a young woman:

You know the funny thing was I got a boyfriend already, he was working at the Banco de Bilbao. When I see boyfriend, no supposed to talk to boyfriend ... if they see you talking to anybody, they fire you and my mother told me if I get out of there before I make a year she going to throw me out the house ... Bad reputation before one year

${ }^{8}$ In the community of Burns, Paulina Lizundia, an immigrant from Euzkadi, was for a period of time the etxekoandrea of the Plaza and later the priest's housekeeper.

${ }^{9}$ Seller, Maxine Swartz, op. cit., p. 21. 
and you can't get a job in another place ... a whole year you got to be at there, like it or not. ${ }^{10}$

Boarding arrangements varied from household to household, where boarders might be permanent or nightly, depending often on the season (Christmas and Easter always brought more visitors). Whatever the specific arrangements, most of the work fell to the women, by adding to the household work load. More people ate more food, dirtied more dishes, and soiled more laundry; boarding arrangements always included washing, and in some establishments, ironing, the bed linen. Only the relatively few wealthy households owned labor-saving devices to make the work easier. Social worker, Margaret Byington, in her work Homestead (1910) found:

that a few steelworkers' homes had gas ranges, water heaters, ironers, or cheap hand-cranked washing machines to lighten the task of keeping clothes clean . . . but the poorest families did not. These were the ones who found it necessary to increase their slender income by taking in boarders. ${ }^{11}$

Byington further goes on to say that "taking lodgers is not giving a home to a friend from the old country nor letting an extra room; it is a deliberate business venture on the part of the family to increase the inadequate income from a man's earnings."12

In order to fill in the technological lag existing in most Basque boarding houses (no washing machines or electric/gas stoves), especially in the American West,

${ }^{10}$ Osa, Margarita, op. cit., 1986. Mrs. Osa also credits this particular job as a unique opportunity for furthering her education, especially in the Spanish language.

${ }^{11}$ Byington, Margaret. Homestead: The Households of a Mill Town (New York: Russell Sage Foundation, 1910): pp. 139 in Susan Strasser, Never Done, A History of American Housework (New York: Pantheon Books, 1982): pp. 154-155.

${ }^{12}$ Ibid. 
young women from the Basque Country were a much needed labor commodity. In 1918, Mrs. Osa's contract was eighteen dollars a month to work as a maid in the Barbero Boarding House in Boise, Idaho. Out of the monthly wages a portion was deducted in order to cover the expense of the passage by ship to New York and train to Boise. Her duties were typical of most domestic jobs, which included the daily cleaning and laundry, but the cooking was usually done by the women who owned the business. She recalls bleeding knuckles due to the extensive use of a scrub board. Cecilia Urizar remembers how much her back ached from endless hours of scrubbing clothes and linens on a board. ${ }^{13}$ Mrs. Lucy Aboitiz Garatea, contracted at the age of fifteen to work in her aunt's boarding house in Boise (the Aguirre Hotel but known as Zapatero's), talks of developing "housemaid's knees" from constantly scrubbing and shining floors. ${ }^{14}$

By the early 1920 s, the city of Boise, Idaho supported twelve Basque boarding houses. While the size, services and construction varied, all were located within the same vicinity creating a unique ethnic community of their own. The Boise Basque Center today stands in this same area of the city and serves the Basque community in much a similar capacity as did the traditional boarding houses (that is, hosting dances, wedding receptions, and monthly dinners for members).

${ }^{13}$ Osa, Margarita, op. cit., and Cecilia Urizar, interview with author, January 28, 1989, Burns, Oregon. Also, neither informant could remember the amount of their passage.

${ }^{14}$ Garatea, Lucy. Conversations with author. As a widow with one child left in the home, Mrs. Garatea returned to the boarding house industry and operated the Plaza Hotel in Burns, Oregon from 1949-1964. 
The sizable numbers of families in the business created not only a strong cultural network, but a competitive environment for the services of dependable domestic female labor. If one establishment mistreated or abused its hired help, the women could easily find employment with another such business or in a private home. A real source of irritation and exploitation for some of the women was the demands of the owner to dance with the customers, regardless of the chores that needed to be completed or were in progress. ${ }^{15}$ While dancing is an ancient and beloved tradition among Basques,it was not compatible with work demands for the women working in the boarding houses. Only after the seemingly endless chores were completed, was dancing a desired part of the women's sphere. Then, as willing participants, they could execute, with grace and exuberance, the charm and agility of Basque dancing.

In their chapter titled, "Ethnicity Maintenance" in Amerikanuak, Douglass and Bilbao concur with the testimonies of these women and state:

The hotels occasionally sponsored dances that were sure to be attended by the few unattached Basque girls in the area. The hotels themselves were the greatest source of single Basque girls. Each generally employed two or three, brought out directly from the Basque Country

${ }^{15}$ Osa, Margarita, op. cit. Mrs. Osa never fulfilled her contract with the Barbero establishment. One night while doing laundry in the basement she was asked by the owner to come and dance with one of the men. After dancing one number she was told to go and cook some chorizos (Basque sausages) for the men. While cooking, a man approached and demanded she stop and dance with him. She explained she couldn't and he cussed her out. She still remembers how unusual it was to be called dirty names, something young women were not accustomed to in the Basque Country. Margarita poured the pan of chorizos on the man's head, left, and went immediately to work and live in the home of two women from Ondarroa, Mrs. Isidra Madarieta and Mrs. Anastasia Ocamica. 
... as domestics . . . the majority of whom were married within a few months after reaching the American West. Thus, employment in the hotels ... was the major channel along which young Basque women arrived in the United States. ${ }^{16}$

Most of the women married within one-to-two years after immigrating. An option that employed the females within the home and that did not require an extensive knowledge of English was to invest in the boarding house business in areas where Basques were beginning to congregate, as in Harney County, Oregon.

The Star Hotel, a white, two-story, wood-framed structure built in 1911 and originally used as a maternity home, was the first Basque boarding house in Burns. ${ }^{17}$ The house was and continues to be heated by air from a hard wood fuel furnace located in the basement then circulated through open floor vents. There were eight bedrooms, three on the main floor and five upstairs, and two bathrooms, one on each floor. In addition, the main floor contains a large living room and a kitchen. In 1917, Joaquin "Chino" Berdugo, a former Mexican vaquero for the famous cattle baron, Pete French, purchased the dwelling and converted it into a rooming house. ${ }^{18}$ In July 1926, Berdugo sold the rooming house to Felix and Cecilia Urizar for the sum

${ }^{16}$ Douglass and Bilbao, op. cit., p. 377.

${ }^{17}$ The Star Hotel was built in the Original Town Addition to the City of Burns, Block 11, Tax Lot 3. See account number 447, map 233107 CA 7800, in Harney County Assessor's Office, Burns, Oregon.

18 Joaquin Berdugo purchased the Star on June 12, 1917. Book Z, Page 496, Harney County Assessor's Office, Burns, Oregon. For an account of Berdugo's employment with Pete French see Royal Jackson and Jennifer Lee, Harney County, An Historical Inventory (Burns: Gail Graphics, 1978): pp. 53-54. In Figure 2, a site called Berdugo is located in Catlow Valley and named after this man. 
of thirteen hundred dollars. ${ }^{19}$ The Urizars, had been living in the Andrews area of Harney County and owned a hotel which was conspicuously burned to the ground in 1923. Because of this disaster, the Urizars wanted to relocate closer to Burns. ${ }^{20}$ After the purchase of the Star by the Urizars, the business changed from a rooming house to a boarding house, offering traditional Basque meals to the customers, all of whom were Basque males. If an occasional non-Basque wanted a meal or bed for the night, it was perfectly acceptable. Mrs. Urizar remembers getting quite a few customers, especially on weekends and holidays, from the Central Hotel (also owned by a Basque, Josefa Yriarte Ebar, who provided rooms but not meals). ${ }^{21}$ Likewise, the Commercial Hotel (owned by Martina Ramirez Larraneta) which did not offer meals and was located two blocks from the Plaza, helped generate customers for the Osas. $^{22}$

After twenty years of running the Star, Cecilia and Felix moved to their ranch outside of Burns and sold the business to another former Basque herder, Tomas

${ }^{19}$ Joaquin Berdugo to Felix and Cecilia Urizar, June, 1926, Book 32, Page 496. Harney County Assessor's Office, Burns, Oregon.

${ }^{20}$ Urizar, Ceclia. Interview with author. January 28, 1989, Burns, Oregon. In this discussion Mrs. Urizar claims that the burning of the hotel was a deliberate act of an arsonist, but had no idea who or why.

${ }^{21}$ Ibid.

${ }^{22}$ Mrs. Osa called a large, upstairs bedroom in the Plaza the "Irish Room," because she always rented it to Irish sheepherders when they were in town. This acceptance of non-Basque clients is a marked difference to the findings of Jeronima Echeverria, who states: "every hotelkeeper interviewed in this study used this response . . . 'I'm sorry, there are no rooms' . . . to weed out non-Basques," op., cit., p. 204. 
Zabala for the price of seven thousand dollars. ${ }^{23}$ Along with Cecilia, Felix, and their children went long time boarders who resided with the family on their ranch until their deaths, thereby carrying on the extended family tradition created by the boarding house.

The Star made its final transition in 1958 when Tomas Zabala sold the business to his brother, Pedro and his wife Elvira (who had just recently arrived from Euzkadi with two children, after being separated from her husband who had been working in the U.S. for several years). ${ }^{24}$ In her testimony Elvira remembers what bad shape the house was in and how dirty it was. She states that her son, Joe, at the age of eight, refused to eat for several days in the house until numerous loads of trash were disposed of and the scrubbing and painting had begun. ${ }^{25}$

Pedro and Elvira still reside in the home although it has been closed for some time as a boarding house. On Sundays and holidays, the old-time Basques who live in Burns stop by for coffee royals and usually end up in a rigorous game of mus (Basque version of poker), speaking their ancient and enduring language exclusively. Meanwhile, Elvira is constantly on the go, serving the men, taking care of her

${ }^{23}$ Felix and Cecilia Urizar to Tomas Zabala, July 3, 1947, Book 46, Page 292. Harney County Assessor's Office, Burns, Oregon.

${ }^{24}$ Tomas Zabala to Pedro Sr. and Elvira Zabala, April 26, 1968, Book 84, Page 223, Purchase price eight thousand dollars. Harney County Assessor's Office, Burns, Oregon. This is the formal transition, as Elvira Zabala had been managing the establishment for a decade before the deed was filed.

${ }^{25}$ Zabala, Elvira. Interview with author. January 27,1989, Burns, Oregon. In this interview, Elvira speaks only in Basque and her daughter, Gloria Zabala is the translator. Adding to the conversation and interview is Mrs. Zabala's youngest son, Felix. 
grandchild, Amaia, and if she is lucky enough to sit down, continuing to hand knit a sweater for someone special.

The next structure in Burns to be specifically constructed for a Basque boarding house was The Plaza Hotel; the original stone foundation was built in $1928 .^{26}$ In 1929 Fred H. Goyt sold the original foundation to Marcelino and Margarita Osa for a purchase price of sixteen hundred dollars. ${ }^{27}$ In collaboration with a master carpenter and builder, Claude Brown, Marcelino had the potential residence built in a Spanish-stucco style with three thousand, six-hundred forty-four square feet of living space (Basement: 100, Main Floor: 1,772, Second Floor: 1,772). The structure has nine bedrooms and two bathrooms with a wood stove for heating. The Osas continued to manage The Plaza until 1945, when the business was sold to another Basque couple, Joe and Paulina Lizundia ${ }^{28}$ who then sold the house to a Basque widow, Lucy Garatea, in $1949 .^{29}$ Mrs. Garatea managed the business, as a

${ }^{26}$ The Plaza Hotel was built in the Third Addition to the City of Burns, Block 63, Tax Lot 7 and 8. See Account number 1097, Map 233107 CC 5300 in Harney County Assessor's Office, Burns, Oregon.

${ }^{27}$ Fred G. Goyt to Marcelino and Margarita Osa, October 16, 1929, Book 34, Page 295. Harney County Assessor's Office, Burns, Oregon.

${ }^{28}$ Marcelino and Margarita Osa to Joe and Paulina Lizundia, October 31, 1945, Book 42, Page 322. Harney County Assessor's Office, Burns, Oregon. Like the Urizars, the Osa's moved to another large house and two retired, long-time boarders accompanied them.

${ }^{29}$ Joe and Paulina Lizundia to Lucy Garatea, February 9, 1949, Book 50, Page 271. Harney County Assessor's Office, Burns, Oregon. 
widow with one child at home, until she sold to Bernardo and Maite Andueza ${ }^{30}$ in 1965. The Andueza's kept the Plaza in the family and in 1968, after the death of Bernardo, Maite, wanting to return to Spain, sold the establishment to her sister Maria and brother-in-law, Domingo Lete. ${ }^{31}$ The Lete's managed the Plaza as a functioning boarding house until the early 1980s. Maria did not have boarders after that but she did continue to cater banquets at the Plaza offering Basque-style cooking for the sum of ten dollars per person. ${ }^{32}$ In 1988, the Plaza was sold for the first time to a non-Basque, who does not operate or utilize the structure as a hotel or boarding house..$^{33}$ The house, badly in need of repairs, is sadly quiet; without the music, lively conversation and delicious aromas emanating from its interior.

The transformations that resulted in the Star and Plaza were accompanied by changes in the lives of the Basque immigrant women. The subsequent chapter

${ }^{30}$ Lucy Garatea to Bernardo and Maite Andueza, July 27, 1965, Book 78, Page 51. Harney County Assessor's Office, Burns, Oregon.

${ }^{31}$ Maite Andueza to Domingo and Maria Lete, January 31, 1968, Book 83, page 589, purchase price five thousand dollars and any Bancroft liens. Harney County Assessor's Office, Burns, Oregon.

${ }^{32}$ Lete, Maria. Interview with author. August 17, 1989, Burns, Oregon. Maria talks about the banquet she catered for then Governor of Oregon, Vic Atiyeh, and remembers how strange it was to have guards stationed at every entrance. Maria also performed an eighteen-year ritual for U.S. Congressman, Robert Smith, by cooking his favorite Basque dishes and sending them via car (usually with State Senator, Eugene Timms) to Salem for a yearly golf tournament.

${ }^{33}$ Domingo and Maria Lete to Dennis Barrett, June 2, 1988, fee \#880770, purchase price, twenty-nine thousand dollars. Harney County Assessor's Office, Burns, Oregon. 
discusses the transition from Basque "serving girl"134 to the etxekoandrea. The task which distinguished the etxekoandreak from serving girl status was the successful management of the boarding houses. The income from establishments such as the Star and Plaza, which served the Harney county Basque community from 1926 until the 1970s, both added substantially to the economic well-being of the family and helped to maintain ancient Basque customs in the Pacific Northwest.

The etxekoandreak were able to broaden the traditional processes of cultural and social reproduction whereby the role of women was two-fold: 1) they were responsible for reproducing the next generation of laborers and 2) they were also responsible for the daily maintenance of the labor force. The paradoxical effects of the fusion of older Basque processes with currents drawn from the new American environment is perhaps nowhere more clearly shown than in the seclusion which became the way of life for many of the etxekoandreak. A more powerful role in the economic life of the family led, in some cases, to a decrease in community interaction due to both the language barrier and the demands that accompanied the newly broadened labor role of the women.

${ }^{34}$ This term is frequently used to describe the young Basque women who were employed in the boarding houses before marrying and establishing their own businesses. See Douglass and Bilbao for an example of this usage. 


\section{CHAPTER IV}

\section{FROM 'SERVING GIRLS’ TO ETXEKOANDREAK}

Immigrant Basque couples took in boarders primarily for economic considerations and benefited by the availability, even in times of sickness or unemployment, of a gain in flexibility in terms of potential family income. Couples willing to accept boarders built or adapted large dwelling units to accommodate the needs of single immigrants, usually drawn from their own social level and often from the same town or province. ${ }^{1}$ Realized income for work performed by the extekoandreak stabilized the economy of the household and in some cases afforded widows and single women an opportunity to maintain their own households rather than relying on kin. ${ }^{2}$

${ }^{1}$ The Basque community of Burns has always included immigrants from nearly all areas of Euzkadi, although the majority are from the province of Bizkaia. This ratio also holds true for other Basque enclaves in Oregon and Idaho (i.e., Jordan Valley, Ontario, Boise, Caldwell, and Mountain Home).

${ }^{2}$ In 1948, Lucy Garatea, who had been widowed since 1935, bought the Plaza Hotel and moved to Burns from Emmett, Idaho. Accompanying her were her three adult sons (just returning from service in the Armed Forces), and one teenage daughter. Together the family remodeled the existing structure and Mrs. Garatea successfully owned and managed the business alone until 1964. Also, an account of Santa Guisasola Bilbao, an immigrant Basque women, and her boarding house in Twin Falls, Idaho exists at the Idaho Historical Society Library in Boise. The biography, as told by her daughters, sketches her life from a single immigrant woman, to wife, mother and later, a divorcee. This story gives an intimate glimpse into the life inside a Basque boarding house (recipes, celebrations, and anecdotes) as well as the independent and determined etxekoandrea, Santa. 
Theoretically, competition in a laissez-faire market produces price elasticity. Price elasticity, quite simply, means that prices have lost their elasticity, resulting in the development of purchasing decisions based on factors other than price. In a competitive market, price elasticity enables consumers to make purchasing decisions based on variations in price. In the absence of competition, when prices within an industry have stabilized at some market-imposed level, price elasticity is the result. In the case of the Basque boarding houses, which usually charged the same rates, the determining dimensions were qualitative rather than quantitative; atmosphere, personal relationships, services, and loyalty.

Former Oregon State Senator, Anthony Yturri, a Basque who was raised in Eastern Oregon, has interpreted the elements of competition and loyalty among the Basques in relation to the boarding houses:

In any small community with a number of Basques, there will be several Basque hotels or boardinghouses. The rivalry between these hotels is most intense and often bitter. Each constantly attempts to do something a bit better than his competitor. Even the people who reside at the different hotels form factions in support of their respective landlords. ${ }^{3}$

In this discussion, Mr. Yturri's use of the phrase "his competitor" clearly ignores the role of the etxekoandreak, who were actually primarily responsible for creating the

${ }^{3}$ Cressman, L.S. and Anthony Yturri. "The Basques in Oregon," in The Commonwealth Review, Vol XV, No. 1, 1938: p. 370. 
attendant atmosphere. This misinterpretation has been fundamental in most analyses of Basque history, thus reflecting a common error in modern historiography. ${ }^{4}$

The story of any Basque boarding house provides evidence of the dominant role played by women in this aspect of New World life. For example, a former Basque boarding house in Jordan Valley was very popular due to its delicious food, a factor which attracted many drop-in customers who knew or had heard about this particular establishment:

Mrs. Madariaga, who came out of Spain in 1910, has lived in Jordan Valley since 1914. She operates a wonderful institution, a Basque boarding house, where one still may obtain for a dollar, quantitatively and qualitatively, one of the finest meals ever served up in the state of Oregon. This Basque cook laments about her inability to obtain all the items which she deems necessary for her meals, especially items from Spain. ${ }^{5}$

For most Basques, the choice of boarding house was often determined by kinship networks or connections with the extekojaun, while in some cases, arrangements were already in place upon the immigrant's arrival. Whatever the situation, once a Basque man chose to live in a certain boarding house, he normally stayed, depending on circumstances such as: the end of a three-year shepherd contract, marriage,

${ }^{4}$ It is surprising that even a leading woman scholar of Basque boarding houses remains doubtful on this issue. See Jeronima Echeverria, op., cit., pp. 186-187, who concludes: "One early resident in 'Basque town' Los Angeles stated that women who worked in the hotels were virtually slaves, performing the variety of tasks needed to keep the enterprise going....At this point, however, one would be hard pressed to claim all women's work in the hotels was more difficult than men's."

${ }^{5}$ Pomeroy, Earl. "Basques: Highway Brings in New Customs" in The Oregonian, August 25, 1946. 
retirement, return migration to Euzkadi, or, in some instances, death. ${ }^{6}$

The former 'serving girls' had gained valuable experience from their early working years in Euzkadi and from pioneer extekoandreak in cities like Boise, Idaho. They learned the art of creating a pleasing and lively atmosphere from such women as Mrs. Gabina Aquirre (who died at the age of 100, June 1990), and Mrs. Asuncion Ysursa (also still living in her nineties), just to name a few. Mrs. Aquirre's establishment, located on Idaho Street (presently an Idaho Historical landmark), in what was then (1915-1960s) known as the "Basque Boarding House District", was popular for its cleanliness and her exceptional cooking abilities. At times one of the rooms in her house served as a maternity ward, where Basque children were born with Mrs. Aquirre performing the duties of a midwife. ${ }^{7}$

There were also other attractions which created the ambience that lured many customers to this place. Mr. Frank Aquirre had been a shoemaker and shoe repairman, therefore the name Zapateros (shoes) became associated with the establishment. Gabina's reputation and the shoe business increased the attractiveness

${ }^{6}$ See Chapter III concerning boarders following the Urizars and later the Osas to their new homes after they had left the boarding house business. In an interview with Margarita Osa Garatea, she talks of one particular Basque, known as Claudio "Calvo" (bald) Mugarza, who virtually, as she describes it: "went along with the Plaza, from my parents' era to the Lizundias' short tenure, and on through my mother-inlaw, Lucy Garatea's sixteen years as the Plaza's extekoandrea." When I was young, Claudio had retired and in essence became another Aititxa (grandfather) to us; so kind, gentle and patient. Also, I recall how he often helped my Amuma (grandmother) Lucy around the large house and yard, unlike most other, employed boarders.

${ }^{7}$ Her niece, Lucy-Aboitiz-Garatea gave birth to three of her four children in the boarding house, Frank, Henry and Rosalina. Her son Joseph was born in a Boise hospital. 
of this popular boarding house, as did a concrete fronton (handball and paddleboard court) which was affixed to the structure. Nothing can describe the emotions that prevail among Basques (mostly, but not entirely, men) while observing a game. ${ }^{8}$ The players are extremely agile, quick, observant and intensely strong. Often the game is played with a paleta (wooden paddle), however the most famous indigenous form of the sport, Jai Alai, is played with a cesta (basket-like object) attached to the player's hand in order to throw and catch the extremely hard and fast-moving ball. ${ }^{9}$ While the intensity of the games mounted, along with that of the audience, Mrs. Aquirre and her newly arrived-teenage niece, Lucy Aboitiz, catered to the requests of the crowd while also arranging for a large dinner.

These games usually occurred on Sundays, so the etxekoandrea, Gabina, had to prepare for the extra people who would later desire a meal and a bed.

${ }^{8}$ While visiting Euzkadi in 1985 and 1988 the writer attended several handball games, where the excitement and talk were similar to that I experienced in Boise as a young girl. The only noticeable difference was the system of betting, which featured one man loudly calling out words not understandable to me, while he also held out a hat containing the bets. In Boise, by contrast, the betting was normally a silent transaction between observers selecting a particular player or team. The audience, of course, was just as noisy as in the Basque Country. Lucy Garatea and her long-time friend Felicia Achabal, both now in their late eighties, still giggle when talking about the spectacle they used to cause during the games. They were beautiful, single teenage girls, from the Old Country. While taking a break from the endless chores, Lucy and Felicia would hang out the window from upstairs cheering on their favorite players. They persisted despite the inevitable chastisement from Tio (uncle) Frank Aguirre for leading the men and the players' attention away from the game and more significantly from the heavy betting going on.

${ }^{9}$ The ancient Basque game of Jai Alai and outstanding indigenous players have been transported to the Eastern United States in places like Miami and Connecticut, where gambling on the players or teams is legal. 
Considering the absence of household technology such as the refrigerator, the electric or gas stove, and washing machine, budgeting, cooking and bedding the extra clientele seems an enormous impossibility in this day of microwaves, dishwashers, dryers, and other modern appliances.

As in most towns with a Basque community, Boise offered alternatives if Zapateros became overcrowded. There was the Valencia, just a block east on Idaho Street, owned by Mr. Benito and Mrs. Asuncion Ysursa, who was also known for her superb cooking. The Ysursas' establishment was larger than most, and therefore could accommodate more drop-in borders. Again the issue of atmosphere arises when discussing the Ysursa Boarding House. Benito was well-known for his proficiency on the guitar, his singing and his dancing. This natural talent enticed other musicians to the Valencia and one could reasonably be assured that live music, singing and dancing would eventually take place. ${ }^{10}$

Located in the Idaho State Historical Society archives is an interview that was conducted with Mrs. Serefina Uberuaga Mendiguren in which she related stories about her parents' boardinghouse at 607 Grove Street in Boise. Mrs. Mendiguren

${ }^{10}$ It should be noted that the Ysursas' children and some grandchildren are still known in the Boise community today as very authentic and graceful Basque dancers. However, it must be kept in mind that Basques, when gathered together, do not necessarily need the accompaniment of musical instruments to suddenly burst into beautiful harmonizing songs and lively dancing. I remember in the early sixties when my mother ran a boarding house in Burns, that on Sundays the men, after playing cards for endless hours, would grab any pot or pan available to use as a percussion instrument, while we all sang and danced. They would sing both the familiar songs and the songs of improvisation; called in the Basque language, Bertsulari (a person who chants/sings in rhyme and improvises, after given a specific topic to discuss, and often against an opponent). 
remembers going from one boarding house to another, especially on Saturdays and Sundays:

We used to go to the Delamar, and they used to have dances there or elso Jayo's--Reme Jayo's (Yturri) folks and Anes Mendiola's folks, they were also named Anuci and Anastacio. ... at Christmas and different times--they just put the chairs on top of the table and Raymond Menique used to play the accordian and we used to have records and tamborine players and spoons. Letemendi's used to have dances too, once in a while ... they'd have something at Letemendi's maybe, and then those guys would come over to our house and then they'd go to the different places, especially during New Year's and Christmas. ${ }^{11}$

Above all, the atmosphere of home was the main attraction. Unlike their more tourist-oriented Nevada and California counterparts, the Basque boarding houses in Burns and Boise were indeed homes, not hotels equipped with separate rooms for dining and drinking. Everyone ate together, either in a large kitchen or if necessary the living room (sala) which was often converted into a larger dining area. Everyone, that is, except the etxekoandrea, who was constantly serving the endless courses of hearty Basque food to her family and boarders.

Likewise, everyone drank together, and as in the Old Country a pitcher of water and a bottle of dark red wine, free of charge, would be placed on the table to accompany the traditional meal. In some instances, a taste of whiskey would be requested by a boarder or visitor before the meal, and in other cases, whiskey was preferred after the meal with coffee and a cigar (in the Basque Country cognac is more common). The whiskey was not free, usually selling for twenty-five cents a

${ }^{11}$ Mendiguren, Uberuaga Serefina. Interview with Lois Palmgren. February 3, 1982, Boise, Idaho. Transcription p. 17. This former boarding house is now a Basque Museum situated next to the Basque Center in Boise. 
drink. The sale of such amenities not only created the main source of profit for these establishments, but it also attracted surveillance, particularly during the era known as Prohibition.

The Volstead Act, passed over President Woodrow Wilson's veto on October 28, 1919, provided for enforcement of the Eighteenth Amendment:

No person, shall ... manufacture, sell, barter, transport, import, export, deliver, furnish, or possess any intoxicating liquor except as authorized in this act, and all the provisions of this act shall be liberally construed to the end that the use of intoxicating liquor as a beverage may be prevented. ${ }^{12}$

The penalties for violation were severe, ranging from a $\$ 500$ fine to one of $\$ 2000$ and five years in prison for repeated offenses. Enforcement of the newly enacted Amendment would have been a formidable task had even a tiny minority of the public been willing to violate the law. The coast lines and land borders of the United States offered an 18,700-mile invitation to smugglers. ${ }^{13}$ Yet, as of 1920 there were only 1,520 prohibition agents on the payroll and as late as 1930 there were fewer than 3,000. Congressman Fiorello LaGuardia said that to monitor New York City alone "will require a police force of 250,000 men and a force of 250,000 men to police the police."14

${ }^{12}$ Maddox, Robert James. "The War Against Demon Rum" in American History, Reconstruction Through the Present, edited by Robert Maddox (Guilford: Dushkin Publishing, 1984): p. 114. National prohibition went into effect January 1920 and lasted until the Eighteenth Amendment was repealed in 1933. Oregon declared statewide prohibition in January 1916. See John E. Caswell, "The Prohibition Movement in Oregon," in Oregon Historical Quarterly, Vol. 15, 1939.

${ }^{13}$ Ibid.

${ }^{14}$ Ibid. 
Other than home manufacture, domestic bootleggers provided the largest source of alcohol. A commercial still which could produce up to one-hundred gallons a day cost only about $\$ 500$. As Robert Maddox states, "The fact that production of corn sugar in 1929 was six times that of 1919 testifies to the hard work and ingenuity of bootleggers ... and much of the alcohol sold was consumed in the home. ..."15

In a study conducted by Sarah Baker Munro titled, "Basque-American Folklore of Eastern Oregon" (M.A. thesis, University of California, 1972) the author concludes that:

The herding stories focus on the confusion and misunderstanding of newcomers to the United States and to an occupation in an alien environment that they felt they must endure to earn money. None of the memorates depict the herder as a heroic figure. The hero among Jordan Valley Basques was the bootlegger [one who transports alcohol] of prohibition days. Sometimes an entire family subsisted on moonshining and bootlegging. The mother of one such family in McDermitt was finally arrested and taken to jail, ... . since they had no bail money. "Take me to jail," she cried, "but feed my kids."16

According to Munro; "McDermitt, on the Nevada-Oregon border, was an ideal location for bootleggers, whose contacts reached across the state."17

During an interview with a former Burns etxekoandrea, a photograph of one the more famous Basque bootleggers from Munro's study came to life. $\quad \mathrm{T} \mathrm{h}$ e woman identified the man in the picture by his nickname, "Macaroni," and proceeded

${ }^{15}$ Ibid, p. 115 .

${ }^{16}$ Baker, Sarah Munro. "Basque Folklore in Southeastern Oregon" in Oregon Historical Quarterly, Vol 76, 1975: pp. 158-160. The author does not discuss in this article why only the woman of the household was arrested, and not her husband.

${ }^{17}$ Ibid, p. 159. 
to recall the time when she had accompanied him on one of his excursions. Having just arrived from the Basque Country, the new immigrant was not yet cognizant of American laws regarding the sale of liquor. She therefore accepted Macaroni's offer to travel with him from Boise to the Nevada border in order to pick up his "loot." This famous bootlegger was also smart, as is proved by his having asked the woman to hide the whiskey bottles on her person, which she did. Upon returning to Boise, unmolested by the "Revs" (the name used for federal agents), Macaroni then fulfilled his part of the bargain and bought the young woman an ice-cream cone. ${ }^{18}$

This story could only have happened to newly-arrived immigrants, because in reality the etxekoandreak had already learned the art of "hiding the booze." Jeronima

Echeverria describes some of the methods used by these clever women:

Hotelkeepers kept wine and other alcoholic beverages on hand for Basque clients . . . One observer noted that "if you didn't have wine [at your hotel], the Bascos wouldn't stay." In order to solve this problem, Anselma, ... developed a number of clever ways to hide alcohol ... A private bottle in the upstairs bathroom, a teapot on the kitchen stove, and a flask tucked into her bra, were Anselma's solutions . . . Despite ingenious decoys, however, the Bakersfield police "pinched" the Amestoys three times. ${ }^{19}$

${ }^{18}$ One of Munro's informants said that the profit per trip was five-hundred dollars for some bootleggers, op., cit., p. 160. The identity of the Basque woman recalling this incident will not be published, for obvious reasons. This rule will also hold true when reference is made to other informants whose activities were, at one time, illegal.

${ }^{19}$ Echeverria, Jeronima, op., cit., pp. 99-100. The exact person or persons who were "pinched" is not discussed, therefore there is no way of knowing if it was Anselma, her husband or both. In this study, Anselma is credited with the purchase of the hotel, by arranging a loan without first consulting her husband Francisco. It is quite possible that as the etxekoandrea, Anselma was the person caught serving the alcohol. 
This situation also existed in Burns, where, during the era of Prohibition, the Basque boarding houses were occasionally invaded by federal agents. ${ }^{20}$ Some informants boldly testify about their own arrests by such men, and one declared that "if she had to do it over again [sell whiskey illegally], she would." She clearly explained that her position and responsibilities at the time--a seriously ill and unemployed husband, young children, and the full-time requirements of her job as manager of a boardinghouse--provided ample reasons for defying the law in order to earn money.

Another such informant from Burns proudly describes her arrest and how she outsmarted the agents, who undoubtedly underestimated this non-English speaking woman. While her husband was at work, three strange men (one who spoke Italian) knocked at the door and inquired if they could get a meal. Through conversation with the Italian speaker she explained the rules; they had to sit and eat with the others and eat what was already prepared for the evening meal, for the price of seventy-five cents.

They quickly agreed and proceeded to eat in this secluded enclave, what was probably one of the best meals of their lives . After dinner, the etxekoandrea collected the agreed upon price from the strangers and was promptly arrested, because wine had been served with the meal. The men then proceeded to search and destroy her downstairs cellar, which was filled with canned fruits and vegetables,

${ }^{20}$ Federal concern about these small operations in such remote areas seems particularly ludicrous in light of the statistics previously cited regarding the paucity of agents available for surveillance. 
looking for evidence of wine-making on the premise (none of the damages caused by these men were ever replaced). The family's well-liked attorney, Mr. Pat Donegan, won a dismissal of the charges (selling alcohol) based on the fact that; even though only two of the men drank wine with dinner, she had charged all three the same price.

That it was the women of these boarding houses who were arrested, rather than their husbands, establishes the interpretation that it was Basque women, not Basque men, who were actually the managers and caretakers of the boarding houses. Their primary role in founding the community in the Northwest was reflected in the unfortunate attention they received from federal agents. The stigma of these arrests and the corresponding police records later resurfaced in the paranoia and anxiety felt by these women, especially when they were about to obtain their American citizenship during the 1940s. They were extremely afraid that this previous history would hinder the possibilities of gaining American citizenship status. Fortunately, they were certified and no charges of former illegal activities were brought into the proceedings.

The cash register was conspicuous by its absence in the boarding houses. In reality, there was no need for one as the etxekoandreak used the same system of payment that is still practiced today in the small towns of Euzkadi. That is, a customer pays when finished and ready to leave, and pays the amount requested without question. Just as in the boarding houses, there is no need for receipts because the customer has complete trust in the system. This type of payment was 
not always easy for the etxekoandreak, especially on busy days, for they never wrote anything down and when customers were ready to leave she had to know exactly how much was owed by each individual. ${ }^{21}$ Often one person would order a round of drinks and expect the etxekoandrea naturally to understand that he would eventually be responsible for payment of that round. When this went on all day with each customer ordering rounds and often food, mental calculation must have been quite difficult.

Interviews with former etxekoandreak all contain the same theme: hard work. Daily responsibilities lasted from sunup to sundown, the women enjoyed no vacations, and they usually labored with very little help. The etxekoandreak who had daughters were fortunate because these girls became additional laborers within the boarding house. The endless hours of cleaning, washing and ironing sheets and making numerous beds were lessened if one had daughters to help complete the requisite tasks. It is this first American-born generation of Basques that will be discussed in Chapter Five. Along with their testimonies and those of several non-Basque observers, as well as those of the grandchildren, the discussion includes first-hand knowledge of what life was like growing up in and around a Basque boarding house.

${ }^{21}$ Mrs. Maria Lete credits her husband, Domingo, for helping her keep track of the drinks and food consumed during busy days at the Plaza. Margarita Osa Garatea remembers being teased by her Basque clients because she would tally their drinks when it got busy. They assumed that since she was an American-born Basque, she had not quite grasped the system as had her mother, Margarita Osa and the others from the Old Country. 


\section{CHAPTER V}

\section{LIFE IN A BOARDING HOUSE: \\ THE FIRST AMERICAN-BORN GENERATION REMEMBERS}

The experiences of the first American-born generation of Basques reflected that of other immigrant groups in the United States. Although boarding houses nurtured the older emigres' tenacious maintenance of Old Country customs and values, other forces worked to separate Basque children from their European heritage. While public schools operated to acclimatize students to American ways, the less formal processes of everyday life also encouraged this younger generation's impulse to achieve acceptance via conformity with majority-group expectations.

Widespread informal sentiment against minority groups and activities was buttressed by formal support for use of the English language and opposition to foreign cultural values and ethnic organizations. An early twentieth century educator articulated this thread in a manner that also pointed to deeper racial and cultural antecedents:

Everywhere these people tend to settle in groups or settlements, and to set up here their national manners, customs, and observances. Our task is to break up these groups or settlements, to assimilate and amalgamate these people as a part of our American race, and to implant in their children, so far as can be done, the Anglo-Saxon conception of righteousness, law and order, and popular government, and to awaken in them a reverence for our democratic institutions and 
for those things in our national life which we as a people hold to be of abiding worth. ${ }^{1}$

While there was change in the tone and suggested applications of such strong nativist opinions during the course of the century, the impact of processes growing from these attitudes is apparent in the assimilation of earlier first-born generations to American ways. Thus, while children born in the $1920 \mathrm{~s}$ and $1930 \mathrm{~s}$ often understand the Basque language, they normally are no longer fluent. This stands in stark contrast to later first-born generations of Basques who have retained fluency in their ancestral tongue. The less dogmatic approach favored in education during later decades allowed for a cultural dualism to exist.

Still, all of these American-born generations found that existence between two worlds involved stress and a somewhat anomalous lifestyle. Generally however, it is fair to say that the gradual liberalizing of American public opinion on the issue (despite the strident nature of the conflict over bilingual education in the Southwest during the decade of the 1980s) lessened the desire of the later group to become thoroughly Americanized.

Due to the existence of the boarding houses and the continued influx of Basque immigrants, up until the 1970s, the American-born generations are able to

${ }^{1}$ Cubberly, Ellwood P. Changing Conceptions of Education (Boston: Houghton Mifflin, 1909): pp. 15-16, in Vincent N. Parrillo, Strangers to these Shores: Race and Ethnic Relations in the United States (New York: MacMillan Publishing Company, 1986): p. 155. For a fascinating and comprehensive overview of the centrality of this subject to American history see Reginald Horsman, Race and Manifest Destiny (Cambridge: Harvard University Press, 1981). Horsman's treatment of Anglo-Saxon ethnocentrism bears directly on the case of Basque migration to the Pacific Northwest. 
sing and dance exactly as their cousins in Euzkadi, although many have never even seen their Old World relatives or their ancestral homeland. Many Basque- American women cook the same types of food as did their mothers and grandmothers and dress their young children in the same fashion. Basque American men play mus, just like their counterparts in the small bars of the Basque Country, while the women often play $b r i s k a^{2}$ during breaks in the daily chores. Mrs. Serefina Uberuaga Mediguren, who was born in her aunt's boarding house and raised in her mother's, both located in Boise, Idaho, learned to play both mus and briska:

there were card games all the time, ... the men would go out to the pool halls and visit and then they'd come home and mama and I, or the different ones would team up and whoever lost had to buy the chocolate, hot chocolate with doughnuts . . . or else chorizos and eggs, and the loser would have to pay for all of them. So we played mus or briska ... I know a little bit of almost all the games; I can play enough to lose. ${ }^{3}$

Two long-time Burns residents, Mrs. Mary Salsbury and Mrs. Peggy Sitz, spent many of their younger days around the Plaza boarding house. As close friends of Mrs. Margarita Osa's daughters, Consuelo (Connie) and Margarita (Margaret), they became familiar with the daily routine of the boarding house and with the enormous amount of work performed by the females. In a interview Mrs. Sitz states:

I was impressed with the hotel, impressed with living in a hotel. I liked that style they had there ... Perhaps what impressed me most was the men were fed and the women ate later and never seemed to sit down

${ }^{2}$ This is a card game mostly played by the women. In the coastal areas of the Basque Country you can witness this lively card game being played among the older women on the beaches.

${ }^{3}$ Mendiguren, Uberuaga Serefina, op., cit., transcription p. 19. 
and eat with the family ... The women did all the work ... perhaps the men chopped the wood or did the yard work but I don't recall ever seeing them ... although now I often see them working in their yards ... Margaret and Connie did all the cleaning every day and Margarita [Mrs. Osa] did all the cooking ... If the mother did handiwork their children were dressed lovely and this [custom] still continues today. ${ }^{4}$

Mrs. Mary Salsbury remembers being around the Plaza since grade school and how she was always welcomed, but also put to work by Mrs. Osa. Often she was charged with going to the bakery to fetch the numerous loaves of French bread needed for the day, while her playmates, Connie and Margaret, endlessly cleaned the house. She claims their mother was "tough on them, very tough," and in comparison to herself and other contemporaries, "they had to work lots more than any of the rest of us." Mrs. Salsbury also recalls the fun times that were had at the Plaza, such as the festive banquets held in the living room and learning how to count in Basque while "shooting craps" with the boarders. ${ }^{5}$

Beginning in the 1930s, the Basque community of Burns held annual dinner parties during the New Year's celebration. First generation informants remember transporting large pots and pans of traditional Basque food to the location where the two-day festivities were held. They also recall how non-Basques, who had either attended one of the parties or knew of them, would become very friendly before the event in hopes of securing an invitation. Several of these non-Basques consistently

${ }^{4}$ Sitz, Peggy. Interview with author. April 27, 1989, Burns, Oregon.

${ }^{5}$ Salsbury, Mary. Interview with author. May 1, 1989, Burns, Oregon. Mrs. Salsbury's grandfather, Claude Brown, was the builder contracted by the Osas to construct the Plaza in 1929. See Chapter III, p. 38. 
helped with the planning and cooking and were considered integral to the success of the celebrations. ${ }^{6}$

All of the boarding house residents participated in another annual event. Each fall a hog was butchered for the purpose of making chorizos, one of the most favored items in the Basque diet. At the outset, each person was assigned a specific task in the time-consuming process. Several days were needed for the meat to soak in garlic and red pepper sauce; after the meat had been marinated, it was ground, stuffed into casings, tied, and hung to dry. If rationed cautiously the delicious sausages would last until the next fall. Mrs. Mendiguren also remembers this annual occasion:

... they used to butcher a hog, and all the boarders then would stay home and cut up the pork and then she'd [her mother] render the lard, then take about a week or something to cure the meat so they could make the chorizos. Then they'd all get these casings and soak the casings, and then they'd make these long strings of chorizos. Us kids would help because we could tie the strings. Then we'd have to hang them up to dry, either above the cellar or in the dining room. ${ }^{7}$

An Old World superstition in which Mrs. Margarita Osa firmly believed was that if a woman was menstruating during the process of making chorizos, the meat would

${ }^{6}$ Two non-Basques, Robert and Hattie Schroeder, were mentioned by many informants in reference to their assistance at these functions.

${ }^{7}$ Mendiguren, Uberuaga Serefina, op., cit., transcription, p. 9. 
spoil. ${ }^{8}$ Her daughters, Consuelo and Margarita did not mind the prohibition since making the sausages was tedious and messy work.

The daughters of the etxekoandreak were relegated to many chores and often complained of the excessive demands placed on them. Every Saturday the linens were changed, washed and ironed, the floors mopped, waxed and shined, and the furniture dusted. Their daily chores included making the numerous beds, sweeping the floors, carrying wood, doing the endless dishes, and last minute shopping. Mrs. Osa's insistence that they shine the pipes underneath the sinks until they resembled mirrors is well-remembered by her daughters. Only after all the expected chores were completed (often late in the evening), were the young women allowed to do their school work. These dutiful daughters also remember how much love and affection they received from the boarders, who served as surrogate uncles and grandfathers, replacing those they never knew from the Old Country. This attention often lessened the effects of the hard work demanded by the etxekoandreak as necessary to the management of a successful boarding house.

It must be kept in mind that it was not all work and toil in the boarding houses, and many residents of Burns, both Basque and non-Basque, recall the spontaneous festivities in these establishments. The children of Pedro and Elvira Zabala, of the Star Boarding House, remember the night when someone decided

${ }^{8}$ Osa, Margarita. Interview with author, June 24, 1987, Burns, Oregon. Mrs. Osa was seriously injured as a young girl by a cook who hit her when she found out Margarita was in her period and in the kitchen while custard was being prepared. Therefore, she always believed in this superstition when applied to making pudding or sausages. 
there should be a wedding between one of the boarders and an elderly woman visitor. The lace tablecloth was used as the bride's veil, with one of the men assuming the role of the priest, and two children as the flower girl and ringbearer. They not only recall the hilarious ceremony, performed in Basque, but that when the make-believe groom awoke the next morning he actually thought he had married the woman. ${ }^{9}$

The Basque population of Burns began to grow when former sheepherders, who had obtained employment at the Edward Hines Lumber Company, traveled back to Euzkadi, married, and returned to the area with their new brides. The newlyweds' initial days were normally spent in one of the boarding houses, while the etxekoandreak introduced the newcomer to other Basques, and, more importantly, to the customs of America. Often the more experienced immigrant women accompanied the younger arrivals to the hospital when they gave birth, acting as translators and offering comfort during the ordeal. ${ }^{10}$

As the Basque community grew, so did its desire to maintain Old Country rituals such as outdoor festivals which continued for several days. ${ }^{11}$ During the

9 Zabala, Elvira. Interview with author. January 27, 1989, Burns, Oregon. Translation by Gloria Zabala and comments by Felix Zabala.

${ }^{10}$ Mrs. Maria Lete and Mrs. Juanita Andueza called for the assistance of Mrs. Margarita Osa when they gave birth to two of their children. When Mrs. Osa accompanied Mrs. Andueza to Boise for the birth of her daughter, Rosa, Mrs. Elvira Zabala took care of her other children, Eugenio and Ana Andueza, thereby noting the mutual aid within the Basque community of Burns.

${ }^{11}$ In Spain in general, every town has a specific time of the year, usually during the summer months on a saint's day, when their festivals are held. For example; the day of San Juan de Bautista, June 24, is celebrated throughout Spain and Latin America and the most widely-known Basque festival, the running of the bulls in 
celebrations ancient competitive games of wood chopping, weight lifting and dancing were featured, along with singing and an abundance of traditional Basque food and wine. These celebrations are still held annually in most American communities where there is a sizable Basque population (i.e., Boise and Mountain Home, Idaho, and Reno and Elko, Nevada, to name a few). It is quite common to see at these functions children born in the United States dressed in traditional Basque costumes and performing the ancient dances, often to the amazement of newly arrived immigrants who may have never learned the dances themselves.

Sadly, these festivities came to an abrupt halt in Burns during the early 1970 s. The divisive issue which tore the Burns Basque community apart stemmed from the political situation in Spain during the dictatorship of Generalissimo Francisco Franco. In December 1970, the world press focused its attention on a military court-room in the Spanish town of Burgos. Sixteen Basque nationalists, two of whom were priests, were tried for a variety of offenses, including an alleged assassination. Six of the accused were sentenced to death and their sentences were commuted only after the exertion of great international pressure upon Spain's government. The trial proved to be a serious embarrassment to the Spanish military and state. The defendants and their lawyers exposed the political nature of the proceedings and skillfully exploited an opportunity for publicizing their cause. The trial demonstrated to the world the

Pamploma, coincides with the celebration of San Fermin. The annual Basque Picnic in Boise, Idaho is always held in the last week of July around the feast day of San Ignacio de Loyola, the patron saint of the Basques and founder of the Jesuit order (Society of Jesus). 
way in which the Spanish dictatorship dealt with its political opponents and highlighted some of the more arbitrary aspects of the Spanish state's behavior. ${ }^{12}$

Many Basque-American communities accumulated funds or used money from their collective treasuries and sent donations to the families of the accused. A segment of Harney County's Basques also decided to send the money held in the community treasury to the families in Spain. This marked the genesis of the long dispute between the Basques in Harney County. Some Basques felt the money that had been sent was earmarked for the purpose of helping needy Basques in Burns and was not intended for the political strife in Spain. As tempers rose, mediators were called in to try and settle the quarrel, but they eventually had to leave without achieving much success. The two boarding houses became embroiled in the issue with each faction using an establishment as their meeting ground. According to historian, Wilbur Shepperson, this conduct by Burns' Basques was a great departure from the norm:

During the last half-century the Basque country has waged an almost constant battle for political and cultural independence; yet the sons and daughters in America have been almost totally indifferent to the struggle. Although the Basques often seem obsessed by the need for their European homeland and consciously attempt to preserve their society and customs, the cries of the Old World for assistance in opposing the Spanish political centralization ... have generally gone unheeded in the United States. ${ }^{13}$ p. 3.

${ }^{12}$ Medhurst, Kenneth. The Basques (London: Expediate Multiprint, Ltd., 1972):

13 Shepperson, Wilbur. "An Essay on Amerikanuak," in Nevada Historical Quarterly 14 (1976): p. 143. 
The lack of similar occurrences in other Basque-American communities is notable.

This ongoing feud left many scars and created such bitterness that it was no longer possible to hold the annual picnics and parties that were enjoyed in the previous years. The children of the dissenting adults felt great sadness that their once cohesive and unique ethnic group no longer existed and that the joyful celebrations had ended. They also worry about their children never knowing or experiencing an authentic Basque gathering in Burns, especially now that the boarding houses were no longer operating and Basque immigration had virtually ceased.

The deaths of Mrs. Margarita Osa in 1989 and Mrs. Cecilia Urizar in 1990, signaled the end of an important era in both Basque and Harney County history. They were the pioneer etxekoandreak of Burns who raised the first-born and often helped nurture the second and third-born generations of American Basque groups who tenaciously hold on to the heritage passed on to them by these remarkable women. Their presence in Burns is sadly missed by many and their lives and those of other Basque women like them will long be remembered. On the day of Mrs. Osa's funeral the author interviewed some of her grandchildren and great-grandchildren seeking reflections and memories of their Amuma. The following quotes contain the essential insights offered about Mrs. Osa, my grandmother, to whom this work is affectionately dedicated.

Christy Corbet Skold, granddaughter, age 42: What I remember is she instilled pride in me ... I always thought it was special to be Basque. What I will miss the most is her crocheting and the beautiful things she made me. 
Patricia Osa Yriarte, granddaughter, age 39: Because of her we were the closest thing to feeling like a queen; we got to dance, we performed, we socialized ... She taught us so much and she worked so hard ... she fed half this country. Her biggest thing was for us to have fun and be happy.

Ross Corbet, grandson, age 35: She was a real strong-willed person and that, I think, was evidenced by her coming over from the Basque Country alone, as a young girl. Anyone who has ever traveled and lived in a foreign country for a while appreciates the courage that it took to leave their native country and go to a country they'd heard about but didn't really know about. It was a real risk and it takes a strong person to be able to do that. What really comes to mind when I think of Amuma was her love of dancing. When she was dancing there was always a sparkle on her face and I think that is one thing that has been passed down to her children, grandchildren and greatgrandchildren. I'll miss the real sense of history she provided . . . the tie to the past, that's what I'll miss the most.

Dana Osa, granddaughter, age 33: She was always busy cooking and knitting ... she was pretty driven and active and continued to knit up until the moment she died ... . which was good because she did say once that she would die if she could no longer knit. I did learn some of her cooking techniques, especially with fish, but I wish I would have learned more. She never sat down at the table to eat with the rest of us, until she got older, constantly serving everyone, and I often find myself doing the same thing.

Juliane Osa, granddaughter, age 23: I'll always remember her singing and dancing and the food ... I always thought every grandmother was like her but later found out she was one in a million. I will miss her always being there, because you never knew what to expect ... it was always something different and she was so active.

Brett Lambert, great-grandson, age 14: She was a tough woman and I'll never forget her. She just had a lasting personality that sticks with you.

Jonas Marcel Parlor, great-grandson, age 13: I'll miss the meals, playing cards, and just having fun with her. One time, when I was about five, she visited us and we went to the Oregon coast. When she saw that the tide was out she wanted to go on the beach to look for clams. I went wandering off and when I turned around I saw a wave take her out into the ocean and she was floating on her back. When my mom and I pulled her out she just laughed and said she thought God was 
taking her back to Spain. She didn't realize we were at the Pacific Ocean, not the Atlantic, where she was from.

These interviews provide living testimony of the importance Basque-Americans place on retaining their ancient culture and of the respect they hold for their immigrant grandparents who taught them the pride and values of being Basque. The boarding houses served as a vehicle for maintaining these cultural traditions and the women who managed them are largely responsible for the sustained presence of Basque ethnicity in Burns and elsewhere over the past sixty years. In his study on the Basques, Roger Collins concluded:

... the Basques have preserved a distinct identity, and in their small corner of the world and in many places beyond it they have made a unique contribution to the complex web of human history. May they long continue to do so. ${ }^{14}$

The crucial role played by women in the historical process of Basque continuity and cultural endurance has been grossly overlooked by many historians, in both the Old and New Worlds. The reverence that is bestowed on these remarkable women by their families and acquaintances is by the far the most valuable and conclusive evidence of their monumental significance to Basque society and culture.

This study was conducted specifically to help fill this enormous void, not only in Basque history, but also in that of the Pacific Northwest, while further supplementing the important, growing scholarship in womens' history.

${ }^{14}$ Collins, Roger, op., cit., p. 281. 


\section{SELECTED BIBLIOGRAPHY}

\section{BOOKS}

Alegria, Henry. Seventy-Five Years of Memoirs (Caldwell: Caxton Printers, 1981).

Archdeacon, Thomas J. Becoming American: An Ethnic History (New York: Free Press, 1983).

Armitage, Susan and Elizabeth Jameson. The Women's West (Norman: University of Oklahoma Press, 1987).

Bahn, Paul G. Pyrenean Prehistory, A Palaeoeconomic Survey of the French Sites (London: Warminster, Aris and Phillips, 1984).

Bard, Rachel. Navarra, The Durable Kingdom (Reno: University of Nevada Press, 1982).

Baum, Willa K. Oral History for the Local Historical Society (Nashville: American Association for State and Local History, 1975).

Transcribing and Editing Oral History (Nashville: American Association for State and Local History, 1977).

Becker, Carl L. and Leo Gershey. 4th edition. Survey of European History (Boston: Houghton Mifflin, 1969).

Berk, Sarah, ed. Women and Household Labor (London: Sage Publications, 1980).

Bott, Elizabeth. Family and Social Network (London: Tavistock, 1964).

Boyd, William C. Genetics and Races of Man: An Introduction to Modern Physical Anthropology (Boston: Little, Brown and Company, 1950).

Brandes, Stanley. Migration, Kinship and Community: Tradition in a Spanish Village (New York: Academic Press, 1975).

Bridenthal, Renate and Claudia Koonz, eds. Becoming Visible: Women in European History (Boston: Houghton Mifflin, 1977). 
Bridenthal, Renate, Claudia Koonz and Susan Stuard, eds. Becoming Visible: Women in European History, Second Edition, (Boston: Houghton Mifflin, 1987).

Brimlow, George Francis. Harney County, Oregon, and Its Range Land (Portland: Binford's and Mort, 1951).

Calef, Wesley. Private Grazing and Public Lands, Studies of Local Land Management of the Taylor Grazing Act (Chicago: University of Chicago Press, 1960).

Cardozo, Arlene. Women At Home (New York: Doubleday, 1976).

Caro Baroja, Julio. Los Vascos, Etnologia (San Sebastian: Biblioteca Vascongada de los Amigos del Pais, 1949).

Carr, Raymond. Spain: 1808-1975 (Oxford: Clarendon Press, 1982).

Carrol, Bernice. Liberating Women's History (Chicago: University of Chicago Press, 1976).

Castelli, Joseph R. Basques in the Westem United States (New York: Arno Press, 1980).

Cavan, Sherri. Liquor License: An Ethnography of Bar Behavior (Chicago: Aldine, 1966).

Clark, Robert P. The Basques: The Franco Years and Beyond (Reno: University of Nevada Press, 1979).

- The Basque Insurgents: ETA, 1952-1980 (Madison: University of Wisconsin Press, 1984).

Cleland, Robert Glass. Cattle on a Thousand Hills: Southern California 1850-1880 (San Marino: Huntington Library, 1964).

Coles, Robert and Jane Hallowell Coles. Women of Crisis: Lives of Struggle and Hope (New York: Delacorte, 1978). and Dreams (New York: Delacorte, 1980).

Women in Crisis II: Lives of Work and

Collins, Roger. The Basques (New York: Blackwell, 1986).

Cowan, Ruth Swartz. More Work For Mother: The Ironies of Household Technology from the Open Hearth to the Microwave (New York: Basic Books, 1983). 
Crosby, Alfred W., Jr. The Columbian Exchange: Biological and Cultural Consequences of 1492 (Westport, Greenwood Press, 1972).

Crow, John A. Spain: The Root and the Flower (New York: Coward McCann, 1963).

DeCroos, Jean Francis. The Long Journey: Social Integration and Ethnicity Among Urban Basques in the San Francisco Bay Region (Reno: Associated Faculty Press and Basque Studies Program, 1983).

Di Leonardo, Micaela. The Varieties of Ethnic Experience: Kinship, Class, and Gender among California Italian Americans (Ithaca: Cornell University Press, 1984).

Douglass, William A. Beltran: Basque Sheepmen of the American West (Reno: University of Nevada Press, 1979).

. Death in Murelaga: Funerary Ritual in a Spanish Basque Village (Seattle: University of Washington Press, 1969).

- Echalar and Murelaga: Opportunity and Rural Depopulation in Two Spanish Basque Villages (New York: St. Martin's Press, 1975).

Douglass, William A. and Jon Bilbao. Amerikanuak: Basques in the New World (Reno: University of Nevada Press, 1975).

Douglass, William A. and Richard H. Lane. Basque Sheepherders of the American West: A Photographic Documentary (Reno: University of Nevada Press, 1985).

Douglass, William A., ed. Basque Politics: A Case Study in Ethnic Nationalism (Reno: University of Nevada Press, 1985).

Douglass, William A. and Joseph B. Aceves, eds. The Changing Faces of Rural Spain (New York: John Wiley and Sons, 1976).

Douglass, William A., Richard W. Etulain, and William H. Jacobsen, Jr., eds. AngloAmerican Contributions to Basque Studies: Essays in Honor of Jon Bilbao (Reno: Desert Research Institute Publications on the Social Sciences, 1977).

Echeverria, Jeronima. California-Ko Ostatuak: A History of California's Basque Hotels (PhD. Dissertation, North Texas State University, 1988).

Eiguren, Joe. The Basque History: Past and Present. (Boise: Offset Printers, 1972). - Kashpar. (Caldwell: Caxton Printers, 1988). 
Elliot, J. H. Imperial Spain, 1469-1716 (New York: St. Martin's Press, 1963).

Esman, Milton, ed. Ethnic Conflict in the Western World (Ithaca: Cornell University Press, 1977).

Fereday, Lynne. The Basques--A Preservation of a Culture (Boise: Fereday Memorial, 1971).

French, Giles. Cattle Country of Peter French (Portland: Binfords and Mort, 1964).

Gabaccia, Donna R. From Sicily to Elizabeth Street: Housing and Social Change Among Italian Immigrants, 1880-1930 (Albany: State University of New York Press, 1984).

Gallager, Dorothy. Hannah's Daughters: Six Generations of an American Family, 1876-1976 (New York: Crowell, 1976).

Gallop, Rodney. A Book of the Basques. 1930 Reprint (Reno: University of Nevada Press, 1970).

Gamino, Manuel. The Life Story of the Mexican Immigrant: Autobiographic Documents (New York: Dover, 1971).

Gibson, Charles. The Black Legend: Anti-Spanish Attitudes in the Old World and the New (New York: Knopf, 1971).

Gold, Don. Until the Singing Stops; A Celebration of Life and Old Age in America (New York: Holt, Rinehart and Winston, 1979).

Greenleaf, Richard. Zumarraga and His Family Letters to Viscaya, 1536-1548 (Washington, D.C.: Academy of American Franciscan History, 1979).

Greer, Colin,ed. Divided Society: The Ethnic Experience in America (New York: Basic Books, 1974).

Grele, Ronald J., ed. Envelopes of Sound: Six Practitioners Discuss the Method, Theory and Practice of Oral History and Testimony (Chicago: Precedent Publishers, 1975).

Handlin, Oscar. The Uprooted (Boston: Little, Brown and Company, 1951).

. Immigration as a Factor in American History (New Jersey: Prentice Hall, 1959). 
Hansen, Marcus Lee. The Atlantic Migration, 1607-1860 (Massachusetts: Harvard University Press, 1940).

. The Immigrant in American History. Edited by Arthur M. Schlesinger (Cambridge: Harvard University Press, 1942).

Harney, Robert F. and Harold Troper. Immigrants: $A$ Portrait of the Urban Experience 1890-1930 (Toronto: Van Nostrand Reinhold, 1975).

Hayden, Dolores. The Grand Domestic Revolution (Cambridge, Massachusetts Institute of Technology, 1981).

Henige, David. Oral Historiography (New York: Longman, 1982).

Hoopes, James. Oral History: An Introduction for Students (Chapel Hill: University of North Carolina Press, 1979).

Horsman, Reginald. Race and Manifest Destiny (Cambridge: Harvard University Press, 1981).

Howe, Irving. World of Our Fathers (New York: Harcourt, Brace, Jovanovich, 1976).

Ibarruri, Dolores. They Shall Not Pass (New York: International Publishers Company, 1966).

Imamuddin, S.M. A Political History of Muslim Spain (Pakistan: Najmah and Sons, 1961).

Isasi, Mirim. Basque Girl (Glendale: Griffin-Patterson, 1940).

Irigaray, Louis and Theodore Taylor. A Shepherd Watches, $A$ Shepherd Sings (New York: Doubleday, 1977).

Jackson, Royal and Jennifer Lee. Harney County, An Historical Inventory (Burns: Gail Graphics, 1978).

Larea, M. A. and Rafael M. Mieg. Introduction to the History of the Basque Country. Translated by Michael G. Fast. (Madrid: Ediciones Beramar, 1985).

Laxalt, Robert. In a Hundred Graves (Reno: University of Nevada Press, 1972).

- Sweet Promised Land (Reno: University of Nevada Press, 1957). 
Legarreta, Dorothy. The Guernica Generation: Basque Refugee Children of the Spanish Civil War (Reno: University of Nevada Press, 1984).

Lenski, Gerald. The Religious Factor (New York: Doubleday and Company, 1961).

Lesy, Michael. Time Frames: The Meaning of Family Pictures (New York: Random House, 1980).

Lewis, Oscar. A Death in the Sanchez Family (New York: Random House, 1969).

Lockley, Fred. Conversations with Pioneer Women (Eugene: Rainy Day Press, 1981).

Lynch, John. Spain Under the Hapsburgs, Vol. I: Empire and Absolutism 1516-1598 (New York: Oxford University Press, 1964).

McCall, Grant. Basque Americans and a Sequential Theory of Migration and Adaptation (San Francisco: R and E Research Associates, 1973).

McCrindle, Jean and Sheila Rowbotham. Dutiful Daughters: Women Talk About Their Lives (Austin: University of Texas Press, 1977).

Madariaga, Salvador de. Spain, A Modern History (New York: Praeger, 1958).

Maddox, Robert James, ed. American History, Reconstruction Through the Present (Guilford: Dushkin Publishing, 1984).

Malone, Michael P., ed. Historians and the American West (Lincoln: University of Nebraska Press, 1983).

Medhurst, Kenneth. The Basques (London: Expediate Multiprint, 1972).

Monteiro, Mariana. Legends and Popular Tales of the Basque People, 1887. Reprint (New York: Benjamin Bloom, 1971).

Morrison, Joan and Charlotte Fox Zabusky. American Mosaic: The Immigrant Experience in the Words of Those Who Lived It (New York: Dutton, 1980).

Mourant, A.E. Blood Relations: Blood Groups and Anthropology (London: Oxford University Press, 1983).

Novak, Michael. The Rise of the Unmeltable Ethnic (New York: McMillan, 1972).

Ogden, Annegret S. The Great American Housewife: From Helpmate to Wage Earner 1776-1986 (Westport: Greenwood, 1986). 
Olson, James S. Catholic Immigrants in America (Chicago: Nelson-Hall, 1987).

Ott, Sandra. Circle of Mountains: A Basque Sheepherding Community (Oxford: Clarendon Press, 1981).

Parrillo, Vincent. Strangers to These Shores: Race and Ethnic Relations in the United States (New York: MacMillan, 1982).

Payne, Stanley G. Basque Nationalism (Reno: University of Nevada Press, 1975).

Pescatello, Ann M. Power and Pawn: The Female in Iberian Families, Societies, and Cultures (Westport: Greenwood Press, 1976.

Rosengarten, Theodore. All God's Dangers: Life of Nate Shaw (New York: Knopf, 1974).

Russell, P.E. Spain, A Companion to Spanish Studies (London: Methuen and Company, 1973).

Shepperson, Wilbur. Restless Strangers (Reno: University of Nevada Press, 1970).

Sitton, Mehaffey and Davis, eds. Oral History (Austin: University of Texas Press, 1983).

Strasser, Susan. Never Done: A History of American Housework (New York: Pantheon, 1982).

Thorne, Barrie and Marilyn Yalom, eds. Rethinking the Family (New York: Longman, 1982).

Valle, Teresa del, et. al. Mujer Vasca, Imagen y Realidad (Barcelona: Anthropos Editorial del Hombre, 1985).

Weinberg, Roy D. Eligibility for Entry to the United States of America (Dobbs Ferry, New York: Oceana Publications, 1967).

Wentworth, E. N. and C. W. Towne. Shepherd's Empire (Norman: University of Oklahoma Press, 1945).

Woodward, C. Vann, ed. The Comparative Approach to American History (New York: Basic Books, 1968).

Yacom, Margaret Rose. Fieldwork in Family Folklore and Oral History: A Study in Methodology (Doctoral Dissertation: University of Massachusetts, 1980). 
Zinn, Howard. A People's History of the United States (New York: Harper and Row, 1980).

\section{ARTICLES}

Allen, Barbara. "Personal Point of View in Orally Communicated History" Western Folklore 38 (April 1979): pp. 110-18.

Allen, Susan Emily. "Resisting the Editorial Ego: Editing Oral History" Oral History Review 10 (1982): pp. 33-45.

Altrocchi, Julia. "Basque Personalities: Basque Americans in the American Melting Pot," Viltis, Vol XVI (March-April, 1957): p. 20.

Barkham, Selma H. "The Basques, Filling a Gap in Our History Between Jacques Cartier and Champlain," Canadian Geographical Journal (February-March, 1978): pp. 8-19.

Brown, Marley, III. "The Use of Oral and Documentary Sources in Historical Archaeology: Ethnohistory at the Mott Farm," Ethnohistory 20 (Fall 1973): pp. 347-60.

Berg, Amos. "A Native Son Rambles in Oregon," National Geographic, Vol LXV, No. 2, 1934: pp. 173-235.

Campbell, Craig. "The Basque-American Ethnic Area: Geographical Perspectives on Migration, Population and Settlement." Journal of Basque Studies 6 (1985): pp. 83-104.

Caswell, John E. "The Prohibition Movement in Oregon," in Oregon Historical Quarterly, Vol. 15, 1939: p. 82.

Conaway, Charles William. "Lyman Copeland Draper, 'Father' of American Oral History," Journal of Library History 1 (October 1966): pp. 234-35, 238-41, 269.

Crawford, Charlotte. "The Position of Women in a Basque Fishing Community," In Anglo-American Contributions to Basque Studies: In Honor of Jon Bilbao, edited by William A. Douglass, Richard W. Etulain, and William H. Jacobsen, J. (Reno: Desert Research Institute Publications on the Social Sciences, 1977): pp. $145-52$. 
Cressman,L. S. and Anthony Yturri. "The Basques in Oregon," The Commonwealth Review, Vol. XV, No.1, 1938: pp. 367-80.

Douglass, William A. "Basques," In Harvard Encyclopedia of American Ethnic Groups, edited by, Stephen Thernstrom (Massachusetts: Harvard University Press, 1980): pp. 173-78.

. "Counting Basques: The U.S. census." Basque Studies Program Newsletter 28 (November 1983): pp. 3-7.

- "Ethnic Categorization in the 1980 United States Census: The Basque Example." Government Publications Review 12 (1985): pp. 289-96.

. "Home is a Hotel: Nevada's Basque Establishments." Nevada Magazine 39 (Spring 1979): pp. 22-23.

. "Serving Girls and Sheepherders: Emigration and Continuity in a Spanish Basque Village." In The Changing Faces of Rural Spain, edited by Joseph Aceves and William Douglass (New York: John Wiley and Sons, 1976): pp. 45-61.

. "The Vanishing Basque Sheepherder." American West 17 (July-August 1980): pp. 30-31, 59-61.

Esplund, Kandace and Fred Nelson. "Basques in the West" Sunset (June, 1976): pp. 63-65.

Etulain, Richard W. "Basque Beginnings in the Pacific Northwest." Idaho Yesterdays 18 (Spring 1974): pp. 26:32.

- "Basques in Western North American Literature." In Anglo-American Contributions to Basque Studies: Essays in Honor of Jon Bilbao, edited by William A. Douglass and Richard Etulain, and John H. Jacobsen, Jr. (Reno: Desert Research Institute Publication on the Social Sciences, 1977): pp. 7-18.

Faris, David E. "Narrative Form and Oral History: Some Problems and Possibilities," International Journal of Oral History 1 (November 1980): pp. 159-80.

Frank, Roslyn M. "The Religious Role of the Women in Basque Culture." In AngloAmerican Contributions to Basque Studies: Essays in Honor of Jon Bilbao, edited by William A. Douglass and Richard Etulain, and John H. Jacobsen, Jr. (Reno: Desert Research Institute Publication on the Social Sciences, 1977): pp. $153-60$. 
Fry, Amelia R. "Nine Commandments of Oral History," Journal of Library History 3 (January 1968): pp. 63-73.

Glazer, Malbin, Nona. "Housework: Review Essay," Signs: Journal of Women in Culture and Society 1 (1976): pp. 905-22.

Gluck, Sherna. "What's So Special About Women? Women's Oral History," Frontiers 2, Vol. 2 (1977): pp. 3-17.

Greenwood, Davydd. "Continuity in Change: Spanish Basque Ethnicity as a Historical Process." In Ethnic Conflict in the Western World, edited by Milton J. Esman (Ithaca: Cornell University Press, 1977): pp. 81-102.

Grele, Ronald J. "Listen to Their Voices: Two Case Studies in the Interpretation of Oral History Interviews," Oral History 7 (1979): pp. 33-42.

. "Surmisable Variety: Interdisciplinarity and Oral Testimony," American Quarterly 27 (August 1975): pp. 275-95.

. "Can Anyone Over Thirty Be Trusted: A Friendly Critique of Oral History," Oral History Review (1978): pp. 36-44.

Hall, Jacquelyn Dowd. "Oral History Movement: Seeking Out the Voices of Women, Blacks, Radicals, and Workers for a Better-Balanced Story," South Today 4 (April 1973): pp. 2-3.

Hansen, Marcus Lee. "The Third Generation in America." Commentary 14 (November 1952): pp. 492-500.

Harkness, Ione B. "Basque Settlement in Oregon," Oregon Historical Quarterly 34 (December 1933): pp. 273-75.

Heiberg, Marianne. "Inside the Moral Community: Politics in a Basque Village." In Basque Politics: A Case for Ethnic Nationalism, edited by William A Douglass (Reno: University of Nevada Press and Basque Studies Program, 1985): pp. 285-308.

Higham, John. "Immigration." In Comparative Approach to American History, edited by C. Vann Woodward (New York: Basic Books, 1968): pp. 91-105.

Hottinger, Arnold. "The Basques" Swiss Review of World Affairs 29 (October, 1979): pp. 13-23. 
Irastorza, Jose Zapiain. "Mujeres Vascongadas" Vida Vasca (Bilbao and Vitoria, 1958): pp. 113-14.

Jensen, Joan, Beverly Baca, and Barbara Bolin. "Family History and Oral History," Frontiers 2, Vol. 2 (1977): pp. 93-97.

Joyner, Charles W. "Oral History as a Communicative Event: A Folkloristic Perspective," Oral History Review (1979): pp. 47-52.

Kann, Kenneth. "Reconstructing the History of a Community," International Journal of Oral History 2 (February 1981): pp. 4-12.

Kaplan, Thelma. "Women and Spanish Anarchism," In Becoming Visible: Women in European History, Edited by Renate Bridenthal and Claudia Koonz (Boston: Houghton Mifflin, 1977): pp. 400-20.

Levine, Morton. "The Basques" Natural History 76 (April 1967): pp. 45-50.

Link, Diane. "The American Basques." Literature of Ethnic Minorities (Spring 1974): pp. 70-76.

Luebke, Fredrick. "Ethnic Minorities in the American West." In Historians and the American West, edited by Michael P. Malone (Lincoln: University of Nebraska, 1983): pp. 387-13.

Maddox, Robert James. "The War Against Demon Rum," in American History, Reconstruction Through the Present, edited by Robert Maddox (Guilford: Duskin Publishing, 1984): pp. 114-118.

Modell, John and Tamara Hareven. "Urbanization and the Malleable Household: An Examination of Boarding and Lodging in American Families." Journal of Marriage and the Family 35 (1973): pp. 467-79.

Morrissey, Charles T. "The Case for Oral History," Vermont History 31 (July 1963): pp. $145-55$.

Munro, Sarah Baker. "Basque Folklore in Southeastern Oregon," Oregon Historical Quarterly 76 (June 1975): pp. 153-86.

Mourant, A.E. "Blood Groups of the Basques." Nature (October 1947): pp. 505-06.

Myers, Sandra L. "Women in the West." In Historians and the American West, edited by Michael P. Malone (Lincoln: University of Nebraska, 1983): pp. 369-86. 
Nolan, John E. "Life in the Land of the Basques." National Geographic, 105 (February 1954): pp. 147-86.

Norris, Monty. "Chef’s Special." Friends Magazine 36 (October 1979): pp. 26-28.

Okihiro, Gary Y. "Oral History and the Writing of Ethnic History: A Reconnaissance into Method and Theory," Oral History Review 9 (1981): pp. 27-46.

Pomeroy, Earl. "Basques: Highway Brings in New Customs," in The Oregonian, August 25, 1946.

Raphael, Marc L. "Oral History in an Ethnic Community: The Problems and the Promise," Ohio History 86 (Autumn 1977): pp. 248-57.

Reid, Alistair. "Letters From Euzkadi," New Yorker Magazine 37: pp. 171-93.

Robe, Stanley L. "Basque Tales From Eastern Oregon," Western Folklore Vol. XII (1953): pp. 153-57.

Rothman, David. "The Uprooted: Thirty Years Later." Reviews in American History 10 (September 1982): pp. 311-19.

Rubin, Barbara and Doris Friedensohn. "Daughters Interview Mothers: The Questions." Women's Studies Quarterly Vol. 9, No. 2 (Summer 1981): p. 2.

Shepperson, Wilbur. "An Essay on Amerikanuak." Nevada Historical Society Quarterly 14 (Summer 1976): pp. 142-52.

Tamke, Susan S. "Oral History and Popular Culture: A Method for the Study of the Experience of Culture," Journal of Popular Culture 11 (Summer 1977): pp. 267-69.

Tuck, James A. "Discovery in Labrador: A 16th Century Basque Whaling Port and its Sunken Fleet." National Geographic 168 (July 1985): pp. 40-71.

Turner, Fredrick. "Triumph of the 'Bascos'," Country Journal 8 (August 1986): pp. 62-68.

U.S. Department of Interior, Bureau of Land Management, 1984. Taylor Grazing Act In Oregon 1934-1984.

Weiber, Heidi. "The Mining Town Boarding House: A Surrogate Family for the Immigrant." Pennsylvania Ethnic Studies Newsletter (Winter 1985). 


\section{INTERVIEWS}

Andueza, Ana. Interview with author. February 25, 1990, Burns, Oregon.

Arguinchona, Santos. Interview with Royal Jackson. September 24, 1976, Burns, Oregon 1976.

Berridi, Guruzne. Interview with author. July 27, 1988, Ondarroa, Bizkaia, Spain.

Corbet, Osa, Consuelo. Interview with author. February 27, 1989, Burns, Oregon.

Corbet, Ross. Interview with author. May 12, 1989, Burns, Oregon.

Garatea, Osa, Margarita. Interview with author. April 30, 1989, Burns, Oregon.

Hibbard, George. Harney Country History Project, \# 188, Burns, Oregon, 1975.

Hoffman, Lete, Amparo. Interview with author. August 17, 1989, Burns, Oregon. This interview took place along with her mother, Maria Lete.

Lambert, Brett. Interview with author. May 12, 1989, Burns, Oregon.

Larraneta, Martina. Interview with Royal G. Jackson and Jennifer A. Lee. Harney County Basques Oral History Project, September 6, 1976, Burns, Oregon.

Lete, Maria. Interview with author. August 17, 1989, Burns, Oregon. Translation by Amparo Lete Hoffman.

Mendiguren, Sarafina Uberuaga. Interview with Lois Palmgren. Idaho State Historical Society, Oral History Center, February 2-3, 1982, Boise, Idaho.

Osa, Aramaio, Margarita. Interviews with author. March 17, 1986, Boise, Idaho and June 24, 1987, Burns, Oregon.

Osa, Dana. Interview with author. May 12, 1989, Burns, Oregon.

Osa, Julianne. Interview with author. May 12, 1989, Burns, Oregon.

Parlor, Jonas. Interview with author. May 12, 1989, Burns, Oregon.

Rico, Iturrino, Aranza. Interview with author. August 28, 1988, Mutriku, Gipuzkoa, Spain. Translation by Inigo Rico. 
Salsbury, Mary. Interview with author. May 1, 1989, Burns, Oregon.

Sitz, Peggy. Interview with author. April 27, 1989, Burns, Oregon.

Skold, Corbet, Christy. Interview with author. May 12, 1989, Burns, Oregon.

Urizar, Cecilia. Interview with Jackson and Lee, op., cit., Burns, Oregon, August 31, 1976. Interview with author. January 28, 1989, Burns, Oregon.

Yriarte, Osa, Patricia. Interview with author. May 12, 1989, Burns, Oregon.

Zabala, Elvira. Interview with author. January 27, 1989, Burns, Oregon. Translation by Gloria Zabala. Also included in this interview are comments from Elvira's youngest son, Felix Zabala.

Zabala, Gloria. Interview with author. March 17, 1990, Burns, Oregon.

\section{ARCHIVAL SOURCES}

Ada County Court House, Boise, Idaho.

Boise Public Library, Boise, Idaho.

Boise State University Library, Boise, Idaho.

Harney County Court House, Burns, Oregon.

Harney County Library, Burns, Oregon.

Idaho State Historical Society, Boise, Idaho.

Library of Congress, Washington, D.C.

Millar Library, Portland State Universtiy, Portland, Oregon.

Multnomah County Library, Portland, Oregon.

Oregon State Historical Society, Portland, Oregon.

Oregon State Library, Salem, Oregon.

Oregon State University Library, Corvallis, Oregon. 
University of Nevada/Reno Library, Basque Studies Program, Reno, Nevada. University of Oregon Library, Eugene, Oregon. 


\section{APPENDIX}

\section{GLOSSARY OF BASQUE AND SPANISH TERMS ${ }^{1}$}

aitxe - father

aitxitxa - grandfather

aitz - stone

agur - goodbye

andrea $(k)$ - woman, women

$a m a$ - mother

Amerikanauk - Basques in America

$\operatorname{baserria}(k)$ - farmstead(s)

briska - card game played by women

chorizos - Spanish for sausages

eskerrik asko - thank you

etxe - house

etxekoandrea $(k)$ - female(s) head of household

etxekojauna $(k)$ - male(s) head of household

Euskalduna $(k)$ - speaker(s) of the Basque language

${ }^{1}$ The Basque terms are primarily in the Bizkaian dialect, which is the form most used in Burns, Oregon. Note that the plural form of a Basque noun always ends in "k." Spanish words are identified as such. 
Euzkadi - Basque nation

Euskera - Basque language

fiesta - Spanish for festivity or holiday

fors - French term for autonomous rights of Basques in France ending with the French Revolution.

frontón - Spanish for handball court

fueros - Spanish term for autonomous rights of the Basques ending with the Carlist Wars in the 19 th century.

gizona $(k)$ - man, men

izeko - aunt

jai alai - handball game played with a basket

jota - most common dance performed by Basques

kaixo - hello

maitazuna - love

mutil - boy

mutilsara(k) bachelor(s)

mus - card game played by men

neska - girl

neskasara $(k)$ - spinster(s)

ondo - well

osaba - uncle

osasuna - health 
$\operatorname{ostatua}(k)$ - hotel(s) or boarding house(s)

pelota - Spanish for ball or handball game

tia - Spanish for aunt

tio - Spanish for uncle

txapela - traditional Basque hat, often called a beret in French

zoriono $(k)$ - literally good luck, but often used for congratulations and happy birthday 